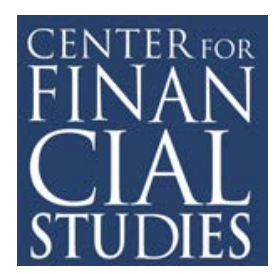

CFS WORKING PAPER

No. 456

The Role of Bank Lending Tightening on

Corporate Bond Issuance in the Eurozone

Orcun Kaya, Lulu Wang 


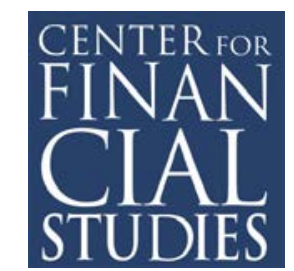

\section{CFS Working Paper Series}

The Center for Financial Studies, located in Goethe University's House of Finance in Frankfurt, is an independent non-profit research center, funded by the non-profitmaking organisation Gesellschaft für Kapitalmarktforschung e.V. (GfK). The CFS is financed by donations and by contributions of the GfK members, as well as by national and international research grants. The GfK members comprise major players in Germany's financial industry. Established in 1967 and closely affiliated with the University of Frankfurt, it provides a strong link between the financial community and academia. CFS is also a contributor to policy debates and policy analyses, building upon relevant findings in its research areas.

The CFS Working Paper Series presents the result of scientific research on selected topics in the field of money, banking and finance. The authors were either participants in the Center's Research Fellow Program or members of one of the Center's Research Projects.

If you would like to know more about the Center for Financial Studies, please let us know of your interest.

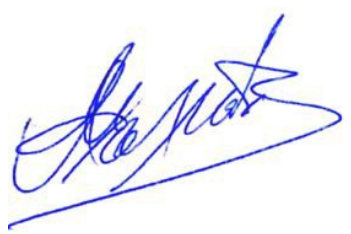

Prof. Michalis Haliassos, Ph.D.
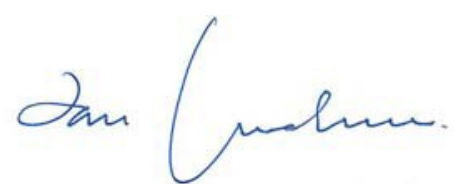

Prof. Dr. Jan Pieter Krahnen

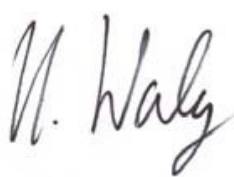

Prof. Dr. Uwe Walz 


\title{
The Role of Bank Lending Tightening on Corporate Bond Issuance in the Eurozone*
}

\author{
Orcun $\mathrm{Kaya}^{\dagger}$ and Lulu Wang \\ Goethe-University Frankfurt
}

April 28, 2014

First Draft July 2013

\footnotetext{
* The authors thank Christian Hirsch, Jan Pieter Krahnen, Thomas Mayer, Christian Wilde, participants of Doctoral colloquium, 2013 Italy, and the seminar participants at the Goethe University, 2013 Frankfurt, for valuable comments and suggestions. The views expressed herein are our own and do not necessarily reflect those of Deutsche Bank AG or Deutsche Bank Research.

† Orcun Kaya (orcun.kaya@db.com) is with the Deutsche Bank Research, Banking, Financial Markets and Regulation, Taunusanlage 12, 60325, Frankfurt, Germany.

${ }^{\ddagger}$ Lulu Wang (wang@ifk-cfs.de) is with Center for Financial Studies, Goethe-University Frankfurt, House of Finance, Grüneburgplatz 1, HPF H5, 603232 Frankfurt; Phone: +49 (69) 79830059.
} 


\title{
The Role of Bank Lending Tightening on Corporate Bond Issuance in the Eurozone
}

\author{
Orcun Kaya $\quad$ Lulu Wang
}

April 28, 2014

\begin{abstract}
This paper empirically tests the role of bank lending tightening on nonfinancial corporate (NFC) bond issuance in the eurozone. By utilizing a unique data set provided by the ECB Bank Lending Survey, we capture the "pure" credit supply effect on corporate external financing. We find that tightened credit standards positively affect the NFC bond issuance in a sample period of 2003 - 2013: a 1pp increase in banks reporting considerable tightening on loans leads to around a $7 \%$ increase in firms' bond issuance in the eurozone. Focusing on a spectrum of aspects contributing to bank credit tightening, we document that banks' balance sheet constraints, as well as the perception of risk lead to significantly higher NFC bond issuance. In addition, we show that stricter lending conditions, such as wider margins, higher collateral requirements and covenants significantly increase NFC bond issuance volumes too. Furthermore, the impact of bank credit tightening on firms' bond issuance is particularly observable in core eurozone countries and not in peripheral countries. This is partially due to the underdeveloped debt capital markets in the peripheral countries.
\end{abstract}

Keywords: Debt Securities, Corporate Financing, Euro Area, Structural Change

JEL-Classification: E44, G23, G32 


\section{Introduction}

Corporate bond issuance in Europe became the focus of attention in the aftermath of the financial crisis. Indeed, outstanding volumes of issued corporate bonds peaked in 2009 for all rating classes and remained at high levels afterwards (Kaya and Meyer (2013)). Admittedly, at times when other means of refinancing, such as bank lending, dry up corporations may naturally tap the debt capital markets. However, unlike their transatlantic counterparts - where tapping the bond market is inherent - debt capital market access in the eurozone is underdeveloped and corporations rely heavily on bank loans for financing. In this respect, a reduction in bank loan availability does not necessarily imply a substitution effect in the eurozone. Therefore, understanding the link between bank loan availability and corporations entering the bond market has a particular importance.

In this paper, we focus on the relation between the volume of non-financial corporations' tapping the bond market and the availability of bank loans in the eurozone on an aggregate level. In doing so, we utilize the bank lending survey (BLS) of the European Central Bank which collects answers on broad as well as detailed questions on the availability of bank loans to non-financial corporations. The first contribution of this paper is to present the impact of bank loan tightening on corporate bond issuance in the eurozone by differentiating between two distinct measures: long term loans and loans to large enterprises. We employ these two measures given that, on the one hand, availability of long term loans is an economically relevant measure as loans are usually supported by a company's collateral in the form of the company's assets and contain restrictive covenants detailing what the company can and cannot do financially during the term of the loan. Consequently, a change in the availability of this measure may create an impetus for bond issuance which also requires long term commitments such as annual coupon payments. On the other hand, there is a fixed cost of entering bond markets which makes it easier for large companies to obtain bond financing than small ones. In this regard, it is relevant to focus on lending to large enterprises as a complementary analysis. Utilizing these two distinct measures and controlling for a number of other variables, we analyze if tightening of lending standards leads to higher corporate bond issuance in the eurozone at the aggregate level (see Becker and Ivashina (2011) for the US at the micro level).

There are various triggers of bank loan tightening which require particular attention. First and foremost, deleveraging in the banking sector, which may affect the liquidity positions of banks, is relevant as it represents a constraint on banks' 
balance sheets. Meanwhile, a sharp decline in bank profitability and deterioration of their capital cushions limit banks' access to wholesale funding. Equally important is a change in the banking sector's perception of risk which may curb banks willingness to provide credits. In this respect, the changes in bank lending conditions and terms reflected by specific obligations agreed upon between banks and NFCs should also be taken into account. The second contribution of this paper is to distinguish between different aspects of bank loan tightening and analyze their impact on corporate bond issuance separately. We focus on the cost of funds and balance sheet constraints of banks, banks' perception of risk as well as the restrictions on conditions and terms for approving loans to enterprises. Specifically, we test if the bank's capital positions, market financing rates and liquidity positions are determining factors in boosting bond issuance. We also test if general economic activity, industry firm outlook and risk on collateral have a role on NFCs utilization of bond market. Moreover, we focus on whether tightening of other factors such as non-interest charges, the size of a loan, amount of collateral required, and loan covenants are relevant in determining the level of the bond issuance in the eurozone.

The third contribution of this paper is to address the cross-country heterogeneity in the bank loan dependence and corporate bond issuance in Europe. Indeed, bond market volumes in peripheral eurozone economies such as Spain and Portugal are small compared to core countries like Germany and France. Therefore, a tradeoff between bank loans and corporate bond issuance could differ between core and peripheral countries and thus, requires further attention.

To summarize, in a sample period of 2003 - 2013, we document that bank lending tightening has a central role in bond issuance in the eurozone. A 1pp increase in banks reporting considerable tightening on long term loans leads to around a $7 \%$ increase in bond issuance in the eurozone. Similar figures are observable for a change in balance sheet constraints of banks or banks anticipating risks on general economic activity: 1pp increase in banks reporting considerable tightening in one of these factors would point to a $5 \%$ to $17 \%$ increase in bond issuance. Among the different tightened terms, non-interest rate charges have the most significant impact with a 1pp increase in banks reporting considerable tightening leading to almost $20 \%$ increase in bond issuance. Although the figures may seem surprisingly large at first glance, it is important to note that changes in these factors do not usually reach the $1 \mathrm{pp}$ level. For instance, of the banks who report considerable tightening during the observation period almost $40 \%$ reported a less than a $1 \mathrm{pp}$ change indicating that a $1 \mathrm{pp}$ increase in tightening is actually a considerable amount in this setting. 
To do the above mentioned analysis this paper is organized as follows. Section 2 develops the research hypotheses. Section 3 introduces related literature. Section 4 presents the research design. Section 5 discusses the data and sample construction. Section 6 provides the empirical results. Section 7 concludes.

\section{Hypothesis Development}

\subsection{Corporate Finance Structure}

In corporate finance, pecking order theory (Meyers (1984)) postulates that external debt financing, either in the form of securities or borrowing, ranks after internal financing when available, but before the "last resort" of raising equity. The reasoning behind this hierarchy lies with the fact that the cost of financing increases with asymmetric information where creditors are not able to write complete contracts covering borrowers' actions in every eventuality. Internal funds are generally considered to be less expensive and immediately available, but are not as flexible, without increase of capital and with limitation in volume. Issuing equity is less desirable where new shares mean bringing foreign ownership into the company and investors often interpret new equity issuance as an adverse signal on the firm value.

As to the source of external finance, the concept of "debt pecking order" is mentioned without an absolute definition (see for instance Haan and Hinloopen (2003)). Debt pecking order stipulates that relationship-based bank loans are favored by companies over publicly-traded bonds in order to minimize adverse selection due to the fact that public investors view bond issuance as a signal for overvaluation. Also, with relationship-based loans companies are able to negotiate or restructure debt in times of distress. Ample studies have analyzed the debt choice of borrowers between intermediated and market funds from both micro and macro perspectives. Factors such as prior capital mix, fixed assets, Tobin's Q and the nature of the industry affect debt financing decisions. Macro-oriented researchers have found the switch of a relationship-based to a market-based financial system to be influential. 


\subsection{Corporate Finance in the Eurozone}

With the break-up of the Bretton-Woods system, the policy-induced innovation of the European Monetary Union (EMU) has promoted the integration of a continental financial market which has a similar scale as the one in the US. The introduction of the Euro eliminated exchange-rate risk. Financial claims are no longer issued in different currencies in the eurozone and the pan-European capital markets have started to emerge. ${ }^{1}$ One of the most significant integration lies in the private-sector bond market in the EMU where the Euro has been preserved as a leading currency of denomination for international bond issues. Rajan and Zingales (2003) find that after the kickoff of the Euro, the growth of the corporate bond market was stronger inside rather than outside the eurozone. As indicated by the BIS statistics, since the inception of the EMU, the issuing volume of private bonds has doubled from $\$ 273$ billion to $\$ 657$ billion in 1999 , where exceptional and transitory factors are mirrored. ${ }^{2}$ Unlike US, corporate funding in Europe is featured with dominant role of bank lending, to the extent that around $75 \%$ of debt financing is funded by banks. ${ }^{3}$ Unlike in the US, European banks serve as both underwriters and lenders, making comparisons of institutional markets challenging. We can see from Figure 1 that both bank loans and the equity market are by far the preferred sources of external refinancing for non-financial corporations in Europe. As shown, for eurozone non-financial corporations' outstanding bank loans and equity issuance amount to EUR 4,388 billion and EUR 14,579 billion, respectively in Q3-2013 compared with only EUR 1,095 billion of corporate bonds and other outstanding debt instruments.

At first glance the share of different sources may mark a large asymmetry in the eurozone corporate funding landscape in terms of the outstanding levels of different liability items at the balance sheets of non-financial corporations. However, the recent crisis has potentially inspired a change in the trend which deserves a great amount of attention: corporates started to use debt capital markets more intensively. One concern might be that the economic downturn induced an expansion in the demand for bonds. Previous frontier literature (Diamond (1991), Rajan (1992), Chemmanur and Fulghieri (1994) and Bolton and Freixas (2000)) documents that the preference for bank debt is due to the monitoring advantage of banks, whereas public debt is more readily available for projects with better

\footnotetext{
${ }^{1}$ It is argued multiple-currency issue is one source of market segmentation. Other frictions exist such as differences in tax treatment, business conventions, issuance policy, security trading and settlement systems, and availability of information (Pagano and von Thadden (2004)).

${ }^{2}$ Such as the financial crisis of late 1998.

3 "European Banking Sector Facts and Figures 2012", European Banking Federation, October 2012 .
} 
quality, larger collateral and less cash flow uncertainty. Thus, during a recession a higher demand for bank loans would be expected. On the other hand, the question of what happens when resources from banks are constrained and when banks are not willing to lend for different reasons remains open.

Corporate banking profitability was severely hit and challenged by the bursting of asset-bubbles during the 2007-2009 episode. The Basel 3 regulatory rules and deleveraging attitude of banks in the aftermath of the credit crunch led to an increase in capital adequacy thresholds, an increase in average funding costs, shrinking of bank balance sheets, and a reduction in overall risk profiles. This scarcity of bank money has arguably fuelled a boom in corporate bond issuance. In times of bank credit shortages, firms that would fulfill needs for cash by obtaining a loan must borrow in the bond market. Taking a closer look at Figure 2, we observe that in contrast to the falling bank lending, non-financial firm bond issuance has surged since end of the subprime crisis. Gross bond issuance reached its highest level, EUR 205 billion in 2009, against a negative bank loan flow of EUR 105 billion. Figure 3 presents a similar picture. Apart from the drop in 2011, the annual growth rate of gross corporate bond issuance has an upward pattern, compared with a rather low growth in bank loans. Numerically, in the post-Lehman era, the growth rate of bonds peaked around $27 \%$ whereas the growth rate of bank loans reached a high at about $11 \%$ and even became negative.

All in all, European non-financial firms seem to have reduced their reliance on bank loans and switched their focus for financing to debt securities. Bearing the above described backdrop in mind, this paper intends to test if the paradigm shift, i.e. the substitution of bonds for loans, is caused by the contraction of bank lending; to statistically analyze the potential factors behind the narrowed lending activity that drove the shift.

\section{Related Literature}

Our paper relates to the strand of the discussion on the relationship between bank borrowing and security issuance, also known as "multiple avenues of intermediation" for corporations. Given the existence of adverse selection (Leland and Pyle 1977) and moral hazard (Diamond 1984) between borrowers and lenders, theories of corporate finance feature an external pattern where banks serve small firms with low levels of public information whereas larger firms, with better public exposure, have the option to be served by the securities market. From the perspective of 
control theory, Bolton and Freixas (2000) present a model where firms that face dilution costs attempt to substitute between loans and bonds, while bank lending is more flexible and expensive.

Kashyap, Stein and Wilcox (1993) use data from the federal fund market to show that tightening of monetary policy leads to a rise in commercial paper issuance when bank lending is flat. They suggest that contractionary policy can indeed reduce loan supply and that this has real effects, for instance, on investment. Drawing on Holmstrom and Tirole (1997), Davis and Ioannidis (2003) highlight the complementarity of bank lending and bond issuance over a volatile period of US financial history.

Becker and Ivashina (2011) is particularly relevant for this study due to its use of US firm-level data in a business-cycle context. They argue that conditional on raising new debt financing, when a firm issues bonds at a time when credit standards are tightening it can be interpreted as a contraction in aggregate bank credit supply. By applying five proxies to track the variation in availability of bank money, they find strong evidence of substitution from loans to bonds at times characterized by tight lending standards, high levels of non-performing loans and loan allowances, low bank share prices and tight monetary policy. Following their set-up, we employ the BLS as an indicator of banks' willingness to lend and test if the bankers' reluctance to offer loans pushes up the alternative financing in the bond market.

Another relevant baseline from the literature involves the decisive elements of corporate debt issuance at a macro level. Indeed, a developed bond market and a sound banking system matter for economic advancement (Herring and Chatusripitak 2000). This in the end measures overall financial credit conditions (Gertler and Lown 2000), and monetary policy transmission through the balance sheet channel. De Bondt (2004) models the macroeconomic determinants of euro-denominated debt securities issued by eurozone non-financial corporations. He concludes that corporate bond activity can be explained by financing costs, financing needs as captured by M\&A and GDP, and the non-price related substitution between debt and other sources of corporate finance. In addition, issued on a more ad hoc basis, short-term debt securities have higher sensitivity to changes in M\&A than long-term debts.

As often occurs in empirical studies, supply effects can be identified from demand. We separate bank loan supply from its demand by exploring the BLS for the eurozone. Ignited from the financial crisis 2007-09, one initial shock to all 
macroeconomic activity comes from the banking sector. In the euro area, banks' profitability and capital cushions have been eroded. This crippled their access to wholesale funding, squeezed their liquidity positions, and threatened their capital positions. Consequently, many banks had to readjust their balance sheets and risk profiles, and retreated from funding the non-financial private sector. The BLS enables us to exploit the "pure" supply-induced reduction on the corporate external financing source by enhancing the knowledge of the role of credit and the importance of banks' decisions in loan growth. Literature on the BLS set gives us a solid reason to inspect the survey.

De Bondt et al. (2010) carry out a country-panel analysis, showing convincingly that the BLS responses on supply standards and demand are reliable measures of credit availability and help explain real GDP growth and non-residential investment growth. Del Giovane et al. (2010) combine the ECB BLS with micro-data on loan quantities and prices from participating Italian banks to assess the importance of supply and demand factors in the sharp fall of credit growth in Italy (strongest after the Lehman collapse). Ciccarelli et al. (2010) use a bank lending survey in Europe and the $\mathrm{US}^{4}$ to distinguish between loan supply and demand and find a significantly stronger impact of a monetary policy shock on GDP once the credit channel is accounted for. Hempell and Sorensen (2010) use a panel econometric approach and look into details of the BLS in order to provide evidence that banks' ability and willingness to supply loans affects bank lending activity in general and particular during the financial crisis. That is, loan growth is negatively affected by supply-side constraints. All in all, empirical studies show that the content in the ECB Bank Lending Survey on banks' assessments of loan supply and demand is indicatively informative on the bank lending activity in the eurozone. Therefore, we step forward and contribute by engaging the ECB BLS as a banking credit supply-proxy, and test how the dropping in this financing source stirs the bond market in Europe.

\footnotetext{
${ }^{4}$ US Senior Loan Officer Survey is the counterpart of ECB BLS in the United States.
} 


\section{Research Design}

\subsection{Causality Effect}

The link between credit supply and the business cycle is revealed (see Holmström and Tirole (1997), Diamond and Rajan (2001) for a detailed discussion) in the literature and suggests that bank lending is more cyclical than bond issuance. In general, elevated levels of capital market funding go hand in hand with subdued levels of bank credit during recessions, for which this time of credit crunch is no exception. Taking the 2000-2013 as our sampling period, we investigate the pairwise relationship between the three sources of external financing by conducting Granger-causality tests (see, Granger (1969) and Sims (1972) for details) based on Vector-Auto Regression (VAR) models to shed light on this relation. We derive the following hypotheses:

Hypothesis 1 (H1): Equity issuance does not "Granger cause" bond issuance; and bond issuance does not "Granger cause" equity issuance.

Hypothesis 2 (H2): Bank loan issuance does not "Granger cause" bond issuance; and bond issuance does not "Granger cause" bank loan issuance.

To test the null, we rely on bivariate VAR models and estimate using OLS:

$$
\begin{gathered}
\text { Bond }_{t}=\alpha+\text { Equity }_{t-n}(H 1) \\
\text { Bond }_{t}=\alpha+\text { Loan }_{t-n}(H 2)
\end{gathered}
$$

Granger-causality test determines whether a time series is useful in forecasting the other where causality implies unique information contained in the causal series for the estimation of the other series. In our analysis, we expect to document a causal relation from bank loan flows to the bond issuance of NFC corporations and no causal relation between equity and bond issuance. This would imply that the NFCs are pushed to debt capital markets only when bank loans are tightened. 


\subsection{Bank Lending Survey}

The BLS ${ }^{5}$ for the eurozone has been conducted by national central banks in collaboration with the European Central Bank (ECB). Since its launch, researchers have shown growing interest in exploring its content (De Bondt et al (2010)). The initial BLS information is from the last quarter of 2002 and is collected at a quarterly frequency. The number of responding banks increased from 86 in 2003 to 118 in $2009,{ }^{6}$ and cover approximately $50 \%$ of total volume of eurozone bank lending to households and non-financial corporations. Although on a voluntary basis, the BLS typically received a $100 \%$ response rate. The data, as argued by the literature, offer almost the only information available on changes in the supply of bank loans in the eurozone (Hempell and Sorensen (2010)). The questions involve bank loans supply/demand to enterprises and households, where we focus on the former. Answers in the questionnaire are categorized into five possible choices of qualitative nature. For example, whether a bank's credit standards, as applied to the approval of loans or credit lines to enterprises, have i) tightened considerably; ii) tightened somewhat; iii) remained basically unchanged; iv) eased somewhat or v) eased considerably. For some questions, there are backward- and forwardlooking time frames to capture both the actual developments and expectations in credit markets.

We collect the BLS data from the ECB website spanning the first quarter of 2003 to the fourth quarter of 2013. Out of the reporting countries in the BLS, our empirical assessment includes countries that have representative corporate bond issues and submit responses to the survey from the beginning. On an EU level, ${ }^{7}$ the ECB reports the results for a percentage of banks in each corresponding answer category. In addition, the survey also gives a net percentage defined as the difference between the responses of tightened minus eased categories, and a diffusion index which adds weights to answer categories and can be interpreted in the same logic of net percentage. On a country level, only the results of net percentage and the diffusion index are available.

Detailed questions on loans or credit lines to enterprises are listed in the Appendix. For the purpose of this paper, we utilize supply-side factors while controlling for

\footnotetext{
${ }^{5}$ The survey is addressed to senior loan officers of a representative sample of euro area banks and will be conducted four times a year. The sample group participating in the survey comprises around 90 banks at the beginning from all euro area countries and takes into account the characteristics of their respective national banking structures. (ECB)

${ }^{6}$ The entry of new euro area countries has also led to an increase in the number of reporting banks over the years.

${ }^{7}$ This is done by aggregating country results after weighting using the national lending in the total amount outstanding of euro area lending to euro area residents.
} 
demand variables. First, we apply the response on how overall credit standards have changed in the previous quarter. For loan approval, Question 1 acts as the indicator of bank loan supply in general, where increasing the percentage of "tightened", as well as "net percentage" and "diffusion index" lead to a decline in supply. Question 6 asks the same question, but in a 3-month forward-looking fashion.

Second, Question 2 itemizes the factors that influence the consistency of credit standards during the bank lending decision making process. It asks: "Over the past three months, how have the following factors affected your bank's credit standards as applied to the approval of loans or credit lines to enterprises (as described in question 1)?" Factors differentiate between: i) costs of funds and balance sheet constraints (with further distinction between "Costs related to your bank's capital position", "bank's ability to access market financing" and "bank's liquidity position"); ii) pressure from competition; iii) perception of risk (separately relating to "expectations regarding general economic activity", "industry or firm-specific outlook" or "risk on the collateral demanded"). Inferring from the studies on the BLS, we look at the most relevant group i) and group iii). We assign the response on a factor of "contributed considerably to tightening of credit standards" to be the proxy of a decline in loan supply.

Third, in Question 3 banks are asked to report how they change credit standards, i.e. "conditions and terms", which range from price-related terms ("bank's margin on average loans" and "bank's margin on riskier loans"), to non-price terms ("noninterest rate charges", "size of the loan or credit line", "collateral requirements", "loan covenants" and "maturity"). We do not examine the credit standards and conditions simultaneously in order to avoid multicollinearity. To better distinguish supply from demand for loans, we further control the change in demand for loans to enterprise. Therefore, we look at Question 4 which asks "over the past three months how has the demand for loans or credit lines to enterprises changed at your bank" and utilize the "net percentage" series. In the following regressions, we work with data in the "tightened considerably" category for Question 1, 2 and 3.

$$
\begin{aligned}
\text { Bond }= & \alpha+B L S Q 1 \_ \text {tight_lending }+\left(B L S Q 4 \_ \text {demand }\right)+\text { Loan } \\
& +\triangle G D P+G o v \cdot \text { BondRate }+ \text { vstox }+ \text { year_fixed }
\end{aligned}
$$




$$
\begin{aligned}
\text { Bond }= & \alpha+B L S Q 2 \text { factor_tight }+\left(B L S Q 4 \_ \text {demand }\right)+\text { Loan } \\
& +\Delta G D P+\text { Gov.BondRate }+ \text { vstox } x+\text { year_fixed }
\end{aligned}
$$

$$
\begin{aligned}
\text { Bond }= & \alpha+B L S Q 3 \_ \text {term_tight }+\left(B L S Q 4 \_ \text {demand }\right)+\text { Loan } \\
& +\triangle G D P+\text { Gov.BondRate }+ \text { vstox }+ \text { year_fixed }
\end{aligned}
$$

\subsection{Core vs. Periphery}

Due to the disproportional impact of the crisis on the peripheral countries, bank lending availability significantly differs between core and peripheral countries in Europe. We go further by analyzing core and periphery economies separately. Although country-level data on the survey are available, we use European level data on the BLS due to the lack of an optimal aggregation method for core or periphery countries as a whole. Our definitions of core and peripheral economies go with the convention. Core countries include Austria, Finland, France, Germany and the Netherlands where peripheral countries are Italy, Portugal and Spain. We exclude countries such as Greece due to small bond market and for Ireland due to limited data, i.e. bond issuance data starting in 2010 .

The following regressions are run:

$$
\begin{aligned}
\text { Core_Bond }= & \alpha+B L S Q 1 \text { tight_lending }+(B L S Q 4 \text { _demand }) \\
& + \text { Core_Loan }+ \text { Core_ } \triangle G D P+\text { Core_Gov.BondRate } \\
& +v s t o x+y e a r \_f i x e d
\end{aligned}
$$

$$
\begin{aligned}
\text { Periphery_Bond }= & \alpha+B L S Q 1 \_t i g h t_{-} \text {lending }+\left(B L S Q 4 \_ \text {demand }\right) \\
& + \text { Periphery_Loan }+ \text { Periphery_ } \triangle G D P \\
& + \text { Periphery_Gov.BondRate }+ \text { vstox }+ \text { year_fixed }
\end{aligned}
$$




\section{Data and Sample Construction}

\subsection{Data Sets}

The main variables of interest of this study are obtained from a publicly available ECB database which provides detailed information about financial markets in Europe. The main variables - debt security issuance volumes - are from the security issues database of the ECB. Meanwhile, the BLS is a data source itself. Macro variables, such as GDP and relevant interest rates, are obtained from the national accounts and long-term interest rate statistics of the ECB database. The Volatility Index EURO STOXX 50 (VSTOXX) comes from STOXX. ${ }^{8}$ Our sampling frequency is monthly for bond security issuance time series and covers the time range between January 2000 and December 2013. We choose January 2000 as a starting point in order to minimize the effect of the birth of Euro in 1999 which led to a structural shift in the corporate debt market. Some macro indicators, such as GDP, are only captured on a quarterly basis due to limitations on the frequency of data. The variables such as MFI loan flow and interest rate have monthly frequency where data from BLS has quarterly frequency and start from 2003. Therefore, the final sample of this study consists of a range from January 2003 to December 2013. For the quarterly variables we use repeated values for the relevant months in a given quarter. Details on abbreviations, definitions and sources of the empirical model variables are given in the Appendix.

\subsection{Descriptive Statistics on Main Time Series}

Table 1 presents the descriptive overview of major time series variables at the EU level for the sample period. For non-financial corporations (NFC), monthly gross bond issuance has a median value of EUR 9.9 billion. A higher mean value for gross bond issuance than the median represents a positively skewed distribution implying that large firms in the capital market are included. Not presented in the Table 1 but worth to mention is the average gross bond issuance of the MFI sector which stands at around EUR 78 billion. This is a considerably higher amount compared to NFC sector. This indicates that the lion's share of privatesector bond issuance in Europe is driven by financial institutions. In fact, the rapid growth of debt securities issued by financial corporations has empowered

\footnotetext{
${ }^{8}$ http://www.stoxx.com/index.html
} 
the eurozone market grow at a similar rate as in the US. MFI loans to $\mathrm{NFCs}^{9}$ stands at around EUR 13 billion on average during the observation period and has a maximum value of EUR 67 billion at the end of 2007. The average GDP growth rate is $0.82 \%$ with a minimum of $-5.46 \%$ in Q1-2009 just after the break-out of the financial crisis and a maximum of 3.8\% in the boom period of the Q4-2006. The average government bond rate is $3.9 \%$ and reached its highest point of $4.8 \%$ in July 2008. The MFI loan interest rate is somewhat higher in general with an average of $4.2 \%$ and a peak of $5.8 \%$ in September 2008 just before the failure of Lehman Brothers. The market can be seen as volatile with the volatility index VSTOXX ranging between 10 and 60 .

Table 2 lists the Pearson pairwise correlations of bond issuance, equity issuance and loan-flow of NFCs. Panel A of Table 2 presents the results for the eurozone whereas Panel B shows the correlation coefficients of only core economies. In all of the specifications the loan flow and bond issuance are significantly negatively correlated. This implies that the two means of corporate financing move in different directions. The negative correlation has a higher scale for the core economies. Nevertheless, this does not automatically imply that core economy firms are more bank-loan dependent. On the contrary, it implies that core economies have a more developed bond market. We find that equity issuance is not significantly correlated with bond issuance or loan-flow. In this respect, this financing channel stands alone and is not influential on other forms of financing for corporations in Europe.

\subsection{Bank Loan Tightening in the Eurozone}

This subsection depicts and describes the attributes of the BLS data. The BLS results for Question 1 are available for long-term loans and loans to large-enterprises. Results for Question 2 and Question 3 are only available for overall loans, as data for large enterprises and SMEs only start from 2008. Figure 4 delineates BLS responses to Question 1, which is the "percentage of banks reporting considerable tightening in bank's credit standards on long-term loans and large-enterprise loans". During the boom years, almost none of the banks report tightening on lending standards and the considerable tightening stands at zero for an extended period. Nevertheless, in the aftermath of the financial crisis, a heightened number of banks report considerable tightening of lending in general. Table 3 presents these trends more clearly and it is observed that on average, more banks re-

\footnotetext{
${ }^{9} \mathrm{MFI}$ loans to the NFCs are in terms of the financial transaction flows and therefore do not allow to differentiate between gross and net issues.
} 
port considerable tightening of lending standards in the long-term and on largeenterprises following the failure of Lehman in Q4-2008 and onwards. For instance, on average considerable tightening to large enterprises loans are 1pp higher than before the break out of the financial crisis.

Figure 5 presents responses to BLS Question 2 which is a follow-up to Question 1. It focuses on detailed factors affecting credit standards tightening which are related to the cost of funds and balance sheet constraints of banks as well as their perception of risk. Figure 5 presents the percentages of banks that report the relevant factor contributing considerably to tightening of credit standards. In contrast to boom periods all factors showed an increased contribution to tightening in general during and after Q4-2008. Because banks were deleveraging due to the regulatory pressure and the sovereign crisis in 2009 the "capital position" and "liquidity position" contributed highly to the tightening of credit standards. Among all factors, perception of risk on "industry or firm-specific outlook" is most widely considered to be a contributing factor when banks construct and tighten their lending guidelines. The second important factor is the uncertainty of "general economic activity". Table 4 presents the descriptive statistics of the factors that contributed considerably to tightening of banks' credit standards. All factors have uniformly higher contributions in the post crisis period. For the entire period, "industry or firm-specific outlook" to be the most pressing factor that led tightening in bank loans. Other factors with the highest contributions at times are: "general economic activity", "risk on collateral" and "capital position". All in all, survey data shows that banks are reluctant to lend when there is a perception of risk in the economy and they de-lever their balance sheets.

Figure 6 presents the results of "considerable tightening" on conditions and terms for approving loans. To differentiate, the impact of price and non-price items are introduced separately in two charts. The same pattern as in Figure 5 is detected: loans or credit lines are more difficult to obtain after Q4-2008. Price terms are stiffened on corporate borrowing. Margins on riskier loans are much higher which implies a wider spread is charged. Among other terms, collateral requirements are the most rigorous from 2009 to 2013. Table 5 presents the BLS statistics on considerable tightening of bank loan conditions and terms. For each contract condition it is observed that more banks report "considerable tightening" on loan margin, loan size, collateral and loan covenants after Q4-2008. In average, banks report almost 2pp higher considerable tightening in margins of the average loans and report almost $1.5 \mathrm{pp}$ higher considerable tightening in margins of the riskier loans. For "non-interest rate charges" which can be, for instance, commitment fees; administration fees or charges for guarantees; a somewhat stable outlook 
is observed. Finally, "loan covenants" seem to be stricter, but present a "net easing" before 2009. Combining Figure 6 and Table 5, the BLS reveals that changes in credit standards are translated into changes in banks' contract terms and conditions: banks tighten their lending through wider margins, higher fees, restricted loan size and more rigid collateral requirements. Firms that could not afford to satisfy certain conditions would not be able to obtain further bank-loan financing.

\section{Empirical Results}

This section presents results for the determinants of corporate bond issuance activity under supply-side impacts which are proxied with the BLS in the eurozone. In our empirical specification, corporate debt security bears the value of gross bond issuance by eurozone NFCs. We start with Granger Causality tests to quantify the validity of our modeling approach and the direction of causality in utilizing BLS questions. We then present the impact of banks' loan tightening on corporate bond issuance activity in Europe. After addressing the effect of overall tightening we delve into different factors regarding banks' cost of funding, balance sheet constraints and perception of risk. We demonstrate the explanatory power of each specific element that boosts corporate bond issuance. In doing this, we disentangle the "pure" loan supply effects stemming from banks' constraints and risk sentiments. We continue by examining how conditions or terms of loan approval alter bond issuance and aim to detect price or volume effects. Finally, we evaluate the cross country heterogeneity in corporate bond issuance by differentiating between core- and periphery- eurozone economies.

\subsection{Granger Causality Tests}

We conduct pairwise Granger Causality Tests up to three lags on three major time series: gross NFC bond issuance, ${ }^{10}$ gross NFC equity issuance and loan flow from MFI to NFC. This is done in a VAR setting by controlling for exogenous variables such as GDP growth, government bond rates and market volatility. Our main focus in this analysis is to evaluate if there is a causal effect between bank loans from MFI to NFC and corporate bond issuance. We also present results for the alternative financing channels, such as equity issuance. As a caveat, we note

\footnotetext{
${ }^{10}$ Includes all debt securities issued.
} 
that we actually test if loan issuance temporally precedes bond issuance with a particular sign or direction, conditional on lagged values.

The results of the Granger causality analysis are given in Table 6 where statistically insignificant values imply absence of causality. As documented in the first two rows of Table 6 , there is no evident and persistent causal relation between equity and bond issuance. Only for the lag 3 there is a weak causal relation from equity to bond issuance. On the other hand, loan flow from MFI granger causes the bond issuance for all lags at statistically significant levels. This attests that the past values of loan flow contain information that helps predict corporate bond issuance above and beyond the information held in future values of bond issue alone. On contrary, there is no causality from bond issuance to loan flow to corporations apart from the one lag specification. The one-sided causality supports the validity of hypothesis to test whether loan supply affects the European corporate bond market.

\subsection{Regressions Based on Overall Changes in Credit Stan- dards (BLS Question 1)}

We now turn to the regression analysis of NFC bond issuance (in logarithm) in the eurozone on changes in the overall credit standards of long-term loans and loans to large-enterprises, i.e. the answers in BLS Question 1. In doing so, we control for a number of additional factors such as loan flow to $\mathrm{NFCs},{ }^{11}$ market volatility, macro variables and year dummies. Our variable of interest - which is the tightening of credit standards - is the internal guidelines or criteria that reflect a bank's loan policy. ${ }^{12}$ In this respect, our results from the BLS serve as the pure bank loan availability indicator and are not affected by external factors that are not related to banks.

OLS estimation results are shown in Table 7. First, two columns denoted by (1) and (2) present the results for long-term loan tightening. The last columns, denoted by (3) and (4), present the results for loans to large enterprises. As seen in model (1) of Table 7, there is a statistically significant and positive impact of banks tightening their loans to NFCs on the firms' bond issuance in the eurozone. Given that the survey question has a three-month backward looking period, the

\footnotetext{
${ }^{11}$ We use quarterly lags of loan flows as suggested by granger causality test and to avoid simultaneity issues.

${ }^{12}$ Such as defining types of loan a bank considers desirable and undesirable; the designated geographic priorities; the collateral deemed acceptable and unacceptable. ECB, Bank Lending Survey
} 
positive impact does not suffer from the problem of simultaneity. "Considerably tightened" credit standards on long-term loan lending in the past quarter happen to exert a significant, positive impact on corporate bond gross issuance during the current period. It could be argued that the availability of loan supply is, to some extent, determined by the demand of corporations for banks' loans and subdued demand may lead to a spurious loan-tightening impact on NFC bond issuance. To address this, we introduce the loan demand of corporations in net percent (BLS Question 4) in model (2) of Table 7. The positive impact of loan tightening is robust to the inclusion of this additional variables and the effect is still statistically significant even after taking into account data on loan demand in previous quarters. ${ }^{13}$ Our results are not only significant in statistical terms, but also the economic impact of the loan tightening is worthy of mention. A $1 \mathrm{pp}$ increase in considerable tightening leads to a $7 \%$ increase in corporate bond issuance. As argued, firms that are curbed by tighter lending standards, face difficulty in acquiring long-term borrowing from banks. As a result and due to the need for financing, they tap the corporate bond market in the subsequent quarter.

It is by now widely accepted that there is a fixed cost associated with tapping the bond market and a corporation's ability to tap the bond markets is positively related with firm size. In this respect, Model (3) and (4) of Table 7 present the results for loans to large enterprises which are more likely to issue bonds. In line with the long-term loan availability impact, the BLS on large-enterprise loans points out that tightening of loans to large-enterprises positively affects bond issuance at statistically significant levels. Moreover, this positive impact is also robust when controlling for the demand of large enterprises for these loans, as documented in Model (4) of Table 7. The figures are also worth mentioning for large-enterprises loans. A 1pp increase in considerable tightening leads to a $6 \%$ increase in corporate bond issuance. ${ }^{14}$

In our specifications we control for various other factors as well. To start with, we control for the real loan flow to non-financial corporations. This has a negative, significant coefficient among all specifications and indicates that positive flow of loans decrease the bond issuance whereas a negative flow has the opposite effect. GDP captures investment and other corporate financing needs related to the busi-

\footnotetext{
${ }^{13}$ Regressions controlling "diffusion index" on Question4 provide the same outcomes.

${ }^{14}$ Bearing in mind the less developed corporate bond market in Europe compare to in US, we ponder the possibility of few large enterprises arousing the bond issuance. As we talked to several bankers professional in European bond market, the industry seems to hold the idea that large enterprise are very much less likely to be bound by lending standards, therefore if big firms had huge bond issues, the results in our regressions are not infected.
} 
ness cycle but the coefficients of GDP are not significant. In line with previous literature, market volatility has a significant and negative influence on bond issuance. Indeed, an increase in market uncertainty is associated with diminished bond returns for firms and creates less incentive to tap the bond markets from a financing perspective. The variable for European government bond rates has an insignificant coefficient throughout our analysis. This result could be associated with the ultra-low interest rate environment in the post-crisis period.

In our analysis we also control for year fixed effects to capture seasonality and the impact of the financial crisis in the markets. As suggested by the previous literature, an F-test on joint significance of these fixed effects is informative. We focus on 2009-2012 year dummies given that credit standards start to ease in 2013 and the most significant tightening was observed just after the failure of Lehman and during the European sovereign debt crisis. The joint significance tests for 2009-2012 are significant when we control for loan demand. This indicates that controlling for year fixed effects is relevant especially during the crisis episode. Furthermore, Durbin-Watson tests confirm that there is no serial correlation in the error component in our setting.

\subsection{Regressions on Factors Contributing Considerably to Tightening of Banks' Credit Standards (BLS Question 2)}

We further investigate the underlying factors that are deemed by banks' senior loan officers as being relevant to lending standards. In Table 8, Panel A displays the results related to the cost of funds and balance sheet constraints. Panel B displays the results for the perception of risk of banks. For each factor presented in Panel A and B we utilize the category "contribute considerably to tightening of credit standards" in Question 2 of the BLS. For all specifications, Model (1) of Panel A and Panel B are presented without the inclusion of demand for loans. In Model (2) we introduce the net loan demand on large-enterprise loans from Question 4 of the BLS. ${ }^{15}$

As described above, Panel A covers the results on "cost of funds and balance sheet constraints" which may inhibit the expansion of bank lending. The motivation for this exercise is that for a given level of capital, a bank's loan supply could be affected by its liquidity position and its access to cash. Indeed, banks could abstain

\footnotetext{
${ }^{15}$ Regressions controlling "diffusion index" on Question4 give the same results.
} 
from granting loans, or are less willing to lend, if they know that they will not be able to transfer the risk or the entire asset off its balance sheet. The outcome of these concerns from the banking sector would certainly affect the landscape of corporate financing. Indeed, we do find a significant and positive impact on gross corporate bond issuance. Namely, when costs related to a bank's capital position, ability to access market financing or liquidity position induce banks to tighten their lending standards, the bank loan market will be somehow narrowed. Thus, corporates would need to refinance via bond markets. Undoubtedly, the liquidity position of banks has a central role in the ability of banks to provide loans and therefore, it has a positive and significant impact in our analysis. A $1 \mathrm{pp}$ increase in the tightening of the liquidity positions of banks is linked with a $7 \%$ increase in bond issuance of corporations. That is, if banks face problems with their liquidity positions, for instance as a result of de-leveraging or regulatory pressure, they may try to improve the liquidity position either by increasing their equity or by lowering their debt. This, in turn, lowers the supply of credits to corporations. The impact of market financing is similar to the liquidity position of banks: if banks themselves have problems in financing their business they will unarguably, have lower incentives to provide loans to corporations. Even though a banks' capital position is similar to the other two, it enters the regression positively but insignificant. It is important to note that even though the figures are somewhat large, changes in the three factors are not large themselves. Almost $40 \%$ of reporting banks express a less than 1pp change in tightening variables.

Panel B shows factors regarding a banks' risk perception. Similar to the balance sheet constraints, risk related factors have positive, significant coefficients and influence gross bond issuance. Put differently, if banks foresee higher risks in "general economic activity", 16 "industry or firm-specific outlook", or "collateral demanded" they considerably tighten their credit standards on overall loans, as a result. Therefore, firms that are consequently kept out of loan borrowing would resort to the bond market for funds as an alternative. In our analysis, perception of risk on collateral demanded has the largest coefficient: 1 pp increase in tightening of bank loans due to risks in collateral demanded results in $17 \%$ more bond issuance. For risk concerns about the general economic activity and industry or firm outlook, a 1pp increase leads to around an $8 \%$ and $5 \%$ increase in bond issuance, respectively.

The contribution of these factors is profound in the crisis years, as presented in Figure 5 and Figure 6. Our results are net of the seasonality in the data given that in all models we control for year fixed effects. Banks' cost of funds, balance

\footnotetext{
${ }^{16}$ This includes changes in the unemployment outlook. ECB, BLS
} 
sheet suppression and their risk awareness contributed to the tightened credit standards during the 2008-2010 period, a shrinking bank loan market and a more active corporate bond market in Europe.

Other control variables in both panels of Table 8 have similar coefficients in terms of statistical significance and magnitude as in Table 7. While loan flow has opposite relation with bond issuance, neither GDP growth nor European government bond rate has a significant effect. Market volatility weakly and negatively correlates with corporates tapping the bond markets. Remarkably, 2009-2012 year fixed effects are jointly significant for all sets of regressions on "general economic activity" and "industry and firm outlook". Taken together, the fact that banks are tightening the lending standards due to a spectrum of different reasons seems to push corporations to search for funding in debt capital markets. Durbin-Watson statistics results again confirm that there is no serial correlation in the data.

\subsection{Regressions on Conditions and Terms for Approving Loans to Enterprises (BLS Question 3)}

When assessing the effect of a tethered loan supply, a practical question is how banks actually implement the restriction. When choosing to tighten overall credit standards: do banks place more strings on loan pricing or fasten requirements on collateral or quantity? The BLS allows analyzing the effects of changes in lending conditions and terms, referred to as specific obligations agreed upon by the lender and the borrower. In Table 9 we present the OLS estimations for the impact of price terms and non-price terms in separate panels. The left-hand variable is the logarithm of non-financial corporate gross bond issue. We take the respondent data on "tightened considerably" in BLS Question 3 as our main regressors and add "net demand" by large-enterprises as control. ${ }^{17}$ Pricing terms are exhibited in Panel A. We find that tightened pricing, i.e. wider margins charged on both average and riskier loans; tend to be followed by significant increase in bond issuance volume in subsequent quarters. More expensive bank loans make alternative financing sources more affordable and push firms to switch to the bond market for funds. Coefficients of "margin on riskier loans" are smaller compared to coefficients of "margin on average loans", but still statistically significant. In economic terms, a 1pp larger margin on riskier loans leads to $3 \%$ higher bond issuance. Moreover, dummy variables for years from 2009 to 2012 are jointly significant with positive signs in regression specification (3) of "margin on riskier

\footnotetext{
${ }^{17}$ Regressions controlling "diffusion index" on Question4 give the same results.
} 
loans". Again, along with wider margins, the financial crisis has its own compelling power on the European corporate bond market.

Panel B contains regressions of gross bond issuance on non-price conditions and terms. Except for "loan covenants", considerable tightening on "non-interest charge", "size of loan" and "collateral required" all significantly and positively correlated with increases in bond issuance. Higher fees which are part of overall pricing of loans, smaller bank loan size available than needed, and more demanding collateral requirements make the desired bank borrowing harder to get and as a result firms that need financing utilize other forms of funding such as public bonds. Among all, non-interest charge has the most severe impact, where a 1 pp increase in fees would result in a $20 \%$ increase in bond issuance. For the tighter loan size and collateral requirement, a 1 pp increase in lead to around $10 \%$ and $14 \%$ increase in corporate bond issuance volume respectively. Together with Panel A, it is plausible to argue that in economic terms, price effects dominate volume effects. A joint significance of the crisis period (2009-2012) is found for "non-interest charge" and "collateral required".

Loan flow and macro controls show a similar pattern of influence as before. Actual bank lending goes in the opposite direction as bonds. While coefficients on GDP growth are insignificant, the bond market is negatively and significantly sensitive to market volatility as before. Serial correlation is not detected in any regression by Durbin-Watson tests.

\subsection{Regressions on Overall Changes in Credit Standards (BLS Question 1) - Core and Periphery Countries}

So far we perform our analysis at the aggregate level and test the hypothesis that tightening in bank loans push companies of the eurozone countries to tap the bond market for funding. However, there are significant differences within the member states of the eurozone (see King (1982)) in terms of tightening of bank loans as well as bond market size and availability. Indeed, highly developed corecountries are characterized by more developed capital markets and investment rate of NFC than peripheral countries. Taken together with the unevenly developed legal frameworks, banking sectors and credit structures of core and peripheral countries make it relevant to analyze the bond market separately. To shed light on the differences on the impact of bank loan tightening on bond issuance between core and peripheral countries, Figure 7 presents the percentage of bonds in the eurozone that are issued in core countries. Figure 7 documents more than $80 \%$ of 
European corporate bond issuance took place in core countries. The mean ratio of core-issue is about $86 \%$, with a maximum ratio of $99 \%$. To go further on this discussion we repeat the analysis of Table 7 and present the results in Table 10 in this subsection. The BLS data are only available for each country in net terms, i.e. a diffusion index and net percentage; therefore we utilize the survey data on the aggregate level for "considerably tightened" overall credit standards.

Panel A lays out the estimation results for core countries. Controlling for loan demand $^{18}$, considerably tightened credit standards on long-term and large-enterprise loans significantly increase the corporate bond issuance with nearly the same economic scale as the one on an aggregated EU level: a 1pp increase in banks reporting considerable tightening on loans leads to around a $7 \%$ increase in firms' bond issuance in the core countries of the eurozone. On the other hand, the coefficients on tightened standards are insignificant for peripheral countries as presented Panel B of Table 10. Put differently, during an economic downturn only the corporates in core countries switch to the bond market for refinancing while firms in peripheral countries could not substitute loans for bonds for funding. Meanwhile, the underlying reason for this discrepancy could well be the lack of a mature bond market in peripheral countries. Even when controlling for the "pure" supply effect, a "substitution" phenomena occurs in core countries alone, rather than European-wide. GDP growth has weak statistical significance in core countries as before, but negatively and significantly influences bond issuance activity in peripheral countries. This in the end may imply a reduction in external funding needs of peripheral countries during recessions. Market volatility has a more material impact on the bond market in peripheral countries where deeper uncertainty boosts bond issuance. Jointly, year fixed effects of the period 20092012 are tested to be significant with positive signs (not reported) in periphery countries. Durbin-Watson tests confirm the absence of serial correlation in both panels.

\section{Conclusions}

The starting point of this paper is the observation of a surging European corporate bond issuance in contrast to shrinking bank loan volumes during the recent economic downturn. Given the background of a long-term domination of banking credit to fulfill corporate external financing in Europe, firms' extensive borrowing in the debt capital market has drawn great attention. Among potential reasons,

\footnotetext{
${ }^{18}$ Regressions controlling "diffusion index" on Question4 give the same results.
} 
we conjecture that in order to endure a severe funding crunch, European banks pulled back from their lending business and this has been a driving force behind the expansion of the corporate bond market in Europe. Indeed, theory predicts the pro-cyclicality of bank loans: not much new credit is issued in recessions. The Basel III-induced rising capital adequacy thresholds lead to higher lending costs. In the aftermath of 2007-2009 subprime mortgage-triggered financial crises, banks in the eurozone began to deleverage, readjust their balance sheets and reduce their risk profile. Together with their overall risk perception, banks' impaired ability and reluctance in lending forced corporates in the eurozone to diversify their funding sources and shift to the bond market for cash. This paper aims to empirically test the role of tightening of bank credit terms in promoting the European bond market growth. We do this by applying a unique data set on banks' lending attitudes, BLS of the ECB for the eurozone.

The BLS, conducted quarterly, is addressed to senior loan officers asking whether their banks' credit standards as applied to the approval of loans to enterprises have tightened or eased; whether the relevant factors, such as cost of funds and balance sheet constraints, or their perception of risk have contributed to the tightening of credit standards; and whether their banks' conditions and terms for approving loans have tightened or eased. With the aid of the informational content in the BLS responses data, we are able to isolate the "pure" credit supply effect of corporate external financing from demand. We found that considerably tightened lending standards explain the upward development of the corporate bond market. In addition, factors that considerably contributed to the tightening of standards, such as eroded capital position, disruption in banks' market financing access, pressure on banks' liquidity and banks' perceived risk on general economic activity, on industry or firm-specific outlook and on collateral demand, all lead to significantly higher corporate bond issuance. Furthermore, using the data on changes in "terms and conditions", we shed light on how banks' lending behavior and loan supply constraints, i.e. via either price charge or non-price rationing, are translated into bond market growth. Considerable tightening on both margins, and non-price terms like fees, loan size, and collateral, significantly drive up corporate bond issuance volume. The results are robust after controlling for actual bank loan flow and bankers' opinion on bank loan demand increase in the BLS. Meanwhile, undoubtedly stark differences in the underlying perspectives between core and periphery eurozone economies suggest a closer look beyond the European level as an aggregate. We find that the above results on increased bond issuance due to tightening on bank credits are significant only in the core countries. This could be partly due to the relatively underdeveloped bond market in 
the peripheral eurozone countries.

Disentangling supply and demand effects on credit developments is always a crucial issue in understanding the credit market dynamics. This is especially true for policymakers, as changes in different and exceptional economic activities require different monetary policy responses through diverse channels. Aside from restricted bank lending, investor demand could be another driving force behind the corporate bond market. Since the outbreak of the sovereign debt crisis, investors have shown great sentiment in search for yield as the government bonds have offered historically low interest rates. Catering for the investors' appetite, nonfinancial corporations take advantage of this by issuing investment grade bonds and raising money in the bond market at a very low cost. Whether investors altered risk-taking is responsible for the upward trend in the corporate bond volume and whether this leads to overheating in the bond market will be a topic of our future research. 


\section{References}

Becker, B. and Ivashina, V. (2011). Cyclicality of credit supply: Firm level evidence. NBER Working Paper No. 17392.

Bolton, P. and Freixas, X. (2000). Equity, bonds, and bank debt: Capital structure and financial market equilibrium under asymmetric information. Journal of Political Economy, Vol. 108(No. 2):324-351.

Chemmanur, T. J. and Fulghieri, P. (1994). Reputation, renegotiation, and the choice between bank loans and publicly traded debt. The Review of Financial Studies, Vol. 7(No. 3):475-506.

Ciccarelli, M., Maddaloni, A., and Peydró, J.-L. (2010). Trusting the bankers: A new look at the credit channel of monetary policy. ECB Working Paper No. 1228.

Davis, E. P. and Ioannidis, C. (2003). External financing of us corporations: Are loans and securities complements or substitutes? Public Policy Discussion Papers 04-02, Brunel University.

de Bondt, G. (2004). The balance sheet channel of monetary policy: First empirical evidence for the euro area corporate bond market. International Journal of Finance and Economics, Vol. 9:219-228.

de Bondt, G., Maddaloni, A., Peydró, J.-L., and Scopel, S. (2010). The euro area bank lending survey matters: Empirical evidence for credit and output growth. ECB Working Paper No. 1160.

de Haan, L. and Hinloopen, J. (2003). Preference hierarchies for internal finance, bank loans, bond, and share issues: Evidence for dutch firms. Journal of Empirical Finance, Vol. 10(No. 5):661-681.

Diamond, D. W. (1984). Financial intermediation and delegated monitoring. Review of Economic Studies, Vol. 51(No. 3):393-414.

Diamond, D. W. (1991). Debt maturity structure and liquidity risk. Quarterly Journal of Economics, Vol. 106(No. 3):709-37.

Diamond, D. W. and Rajan, R. G. (2001). Liquidity risk, liquidity creation, and financial fragility: A theory of banking. Journal of Political Economy, Vol. 109(No. 2):287-327.

Gertler, M. and Lown, C. S. (1999). The information in the high-yield bond spread for the business cycle: Evidence and some implications. Oxford Review of 
Economic Policy, Vol. 15(No. 3):132-150.

Giovane, P. D., Eramo, G., and Nobili, A. (2011). Disentangling demand and supply in credit developments: A survey-based analysis for italy. Journal of Banking \& Finance, Vol. 35:2719-2732.

Granger, C. W. J. (1969). Investigating causal relations by econometric models and cross-spectral methods. Econometrica, Vol. 37(No. 3):424-438.

Hempell, H. S. and Sørensen, C. K. (2010). The impact of supply constraints on bank lending in the euro area - crisis induced crunching? ECB Working Paper No. 1262.

Herring, R. J. and Chatusripitak, N. (2000). The case of the missing market: The bond market and why it matters for financial development. The Wharton Financial Institutions Center Working Paper 01-08, (May).

Holmstrom, B. and Tirole, J. (1997). Financial intermediation, loanable funds, and the real sector. The Quarterly Journal of Economics, Vol. 112(No. 3):663-691.

Ilbery, B. W. (1984). Core-periphery contrasts in european social well-being. Geography, Vol. 69(No. 4):289-302.

Kashyap, A. K., Stein, J. C., and Wilcox, D. W. (1993). Monetary policy and credit conditions: Evidence from the composition of external finance. American Economic Review, Vol. 83(No. 1):78-98.

Kaya, O. and Meyer, T. (2013). Corporate bond issuance in europe. Deutsche Bank Research Article.

King, R. L. (1982). Southern europe: Dependency or development? Geography, Vol. 67(No. 3):221-234.

Leland, H. E. and Pyle, D. H. (1977). Informational asymmetries, financial structure, and financial intermediation. Journal of Finance, Vol. 32(No. 2):371387.

Myers, S. C. (1984). The capital structure puzzle. Journal of Finance, Vol. 39(No. 3):574Ü592.

Pagano, M. and von Thadden, E.-L. (2004). The european bond markets under emu. Oxford Review of Economic Policy, Vol. 20(No. 4):531-554.

Rajan, R. and Zingales, L. (2003). Banks and markets: The changing character of european finance. NBER Working Paper No. 9595. 
Rajan, R. G. (1992). Insiders and outsiders: The choice between informed and arm's-length debt. Journal of Finance, Vol. 47(No. 4):1367-1400.

Sims, C. A. (1972). Money, income, and causality. American Economic Review, Vol. 62(No. 4):540-552. 
Appendix 


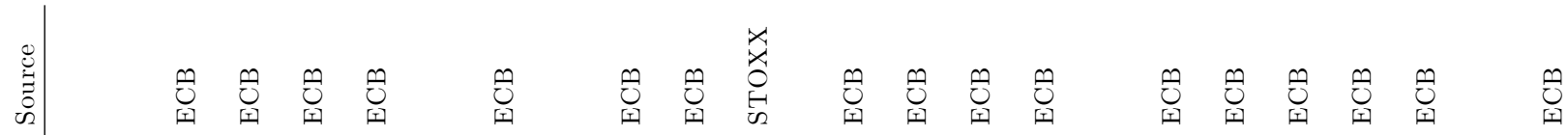

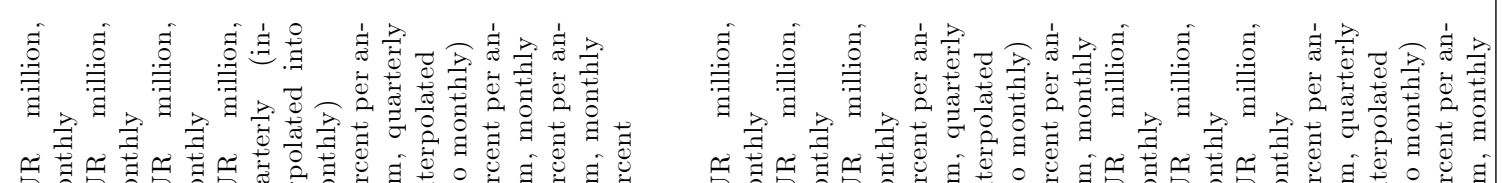

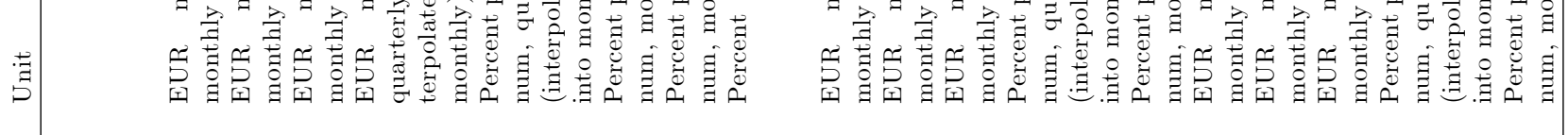

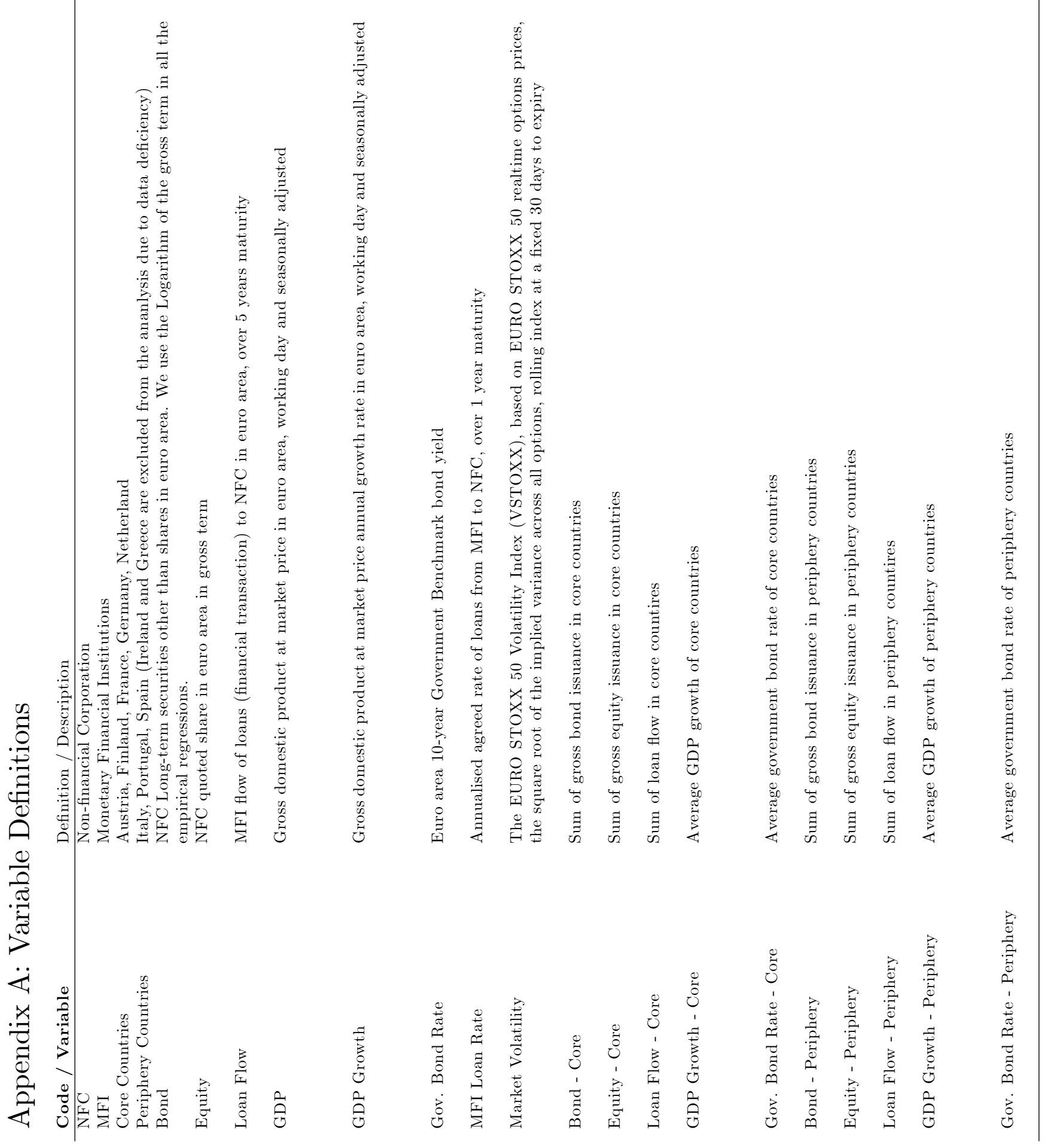




\section{Appendix A: Variable Definitions(continue)}

\begin{tabular}{|c|c|c|c|}
\hline Bank Lending Survey & & Unit & Source \\
\hline LTL & Long-term Loan & & \\
\hline $\mathrm{LE}$ & Large-enterprise Loan & & \\
\hline Overall & Overall Loans & & \\
\hline Net Percentage & $\begin{array}{l}\text { Difference between the share of banks reporting that credit standards } \\
\text { have been tightened and the share of banks reporting that they have } \\
\text { been eased. A positive net percentage indicates that a larger propor- } \\
\text { tion of banks have tightened credit standards ("net tightening"). }\end{array}$ & Percent & ECB, BLS \\
\hline Diffusion Index & $\begin{array}{l}\text { Lenders who have answered "considerably" are given a weight twice } \\
\text { as high (score of } 1 \text { ) as lenders having answered "somewhat" (score } \\
\text { of } 0.5 \text { ). The interpretation of the diffusion indices follows the same } \\
\text { logic as the interpretation of net percentages. }\end{array}$ & Percent & ECB, BLS \\
\hline Considerably Tightened in Q1 & $\begin{array}{l}\text { Percentage of banks reporting "tightened considerably" of bank's } \\
\text { credit standards on long-term loans over the previous quarter }\end{array}$ & Percent & $\begin{array}{l}\text { ECB, BLS } \\
\text { question } 1\end{array}$ \\
\hline Net Percent in Q1 & $\begin{array}{l}\text { Net percentage of banks reporting "tightening" of bank's credit stan- } \\
\text { dards on long-term loans over the previous quarter }\end{array}$ & Percent & $\begin{array}{l}\text { ECB, BLS } \\
\text { question } 1\end{array}$ \\
\hline Considerably Tightened in Q2 & $\begin{array}{l}\text { Percentage of banks reporting a factor to be contributing consider- } \\
\text { ably to tightening of credit standards over the previous quarter }\end{array}$ & & \\
\hline Net Percent in Q2 & $\begin{array}{l}\text { Net percentage of banks reporting a factor to be contributing con- } \\
\text { siderably to tightening of credit standards over the previous quarter }\end{array}$ & & \\
\hline Considerably Tightened in Q3 & $\begin{array}{l}\text { Percentage of banks reporting a condition or term tightened consid- } \\
\text { erably for approving loans over the previous quarter }\end{array}$ & & \\
\hline Net Percent in Q3 & $\begin{array}{l}\text { Net percentage of banks reporting a condition or term tightened con- } \\
\text { siderably for approving loans over the previous quarter }\end{array}$ & & \\
\hline Capital Position & $\begin{array}{l}\text { Percentage of banks reporting "costs related to bank's capital posi- } \\
\text { tion" contributing considerably to tightening of credit standards over } \\
\text { the previous quarter }\end{array}$ & Percent & $\begin{array}{l}\text { ECB, BLS } \\
\text { question } 2\end{array}$ \\
\hline Market Financing & $\begin{array}{l}\text { Percentage of banks reporting "bank's ability to access market fi- } \\
\text { nancing" contributing considerably to tightening of credit standards } \\
\text { over the previous quarter }\end{array}$ & Percent & $\begin{array}{l}\text { ECB, BLS } \\
\text { question } 2\end{array}$ \\
\hline Liquidity Position & $\begin{array}{l}\text { Percentage of banks reporting "bank's liquidity position" contribut- } \\
\text { ing considerably to tightening of credit standards over the previous } \\
\text { quarter }\end{array}$ & Percent & $\begin{array}{l}\text { ECB, BLS } \\
\text { question } 2\end{array}$ \\
\hline General Economic Activity & $\begin{array}{l}\text { Percentage of banks reporting "expectations regarding general eco- } \\
\text { nomic activity" contributing considerably to tightening of credit stan- } \\
\text { dards over the previous quarter }\end{array}$ & Percent & $\begin{array}{l}\text { ECB, BLS } \\
\text { question } 2\end{array}$ \\
\hline Industry or Firm Outlook & $\begin{array}{l}\text { Percentage of banks reporting "industry or firm-specific outlook" } \\
\text { contributing considerably to tightening of credit standards over the } \\
\text { previous quarter }\end{array}$ & Percent & $\begin{array}{l}\text { ECB, BLS } \\
\text { question } 2\end{array}$ \\
\hline Risk on Collateral & $\begin{array}{l}\text { Percentage of banks reporting "risk on the collateral demanded" con- } \\
\text { tributing considerably to tightening of credit standards over the pre- } \\
\text { vious quarter }\end{array}$ & Percent & $\begin{array}{l}\text { ECB, BLS } \\
\text { question } 2\end{array}$ \\
\hline Margin Average Loan & $\begin{array}{l}\text { Percentage of banks reporting "margin on average loans" tightened } \\
\text { (wider margin) considerably for approving loans over the previous } \\
\text { quarter }\end{array}$ & Percent & $\begin{array}{l}\text { ECB, BLS } \\
\text { question } 3\end{array}$ \\
\hline Margin Riskier Loan & $\begin{array}{l}\text { Percentage of banks reporting "margin on riskier loans" tightened } \\
\text { (wider margin) considerably for approving loans over the previous } \\
\text { quarter }\end{array}$ & Percent & $\begin{array}{l}\text { ECB, BLS } \\
\text { question } 3\end{array}$ \\
\hline Non Interest Charge & $\begin{array}{l}\text { Percentage of banks reporting "non-interest rate charges" tightened } \\
\text { considerably for approving loans over the previous quarter }\end{array}$ & Percent & $\begin{array}{l}\text { ECB, BLS } \\
\text { question } 3\end{array}$ \\
\hline Size of Loan & $\begin{array}{l}\text { Percentage of banks reporting "size of the loan or credit line" tight- } \\
\text { ened considerably for approving loans over the previous quarter }\end{array}$ & Percent & $\begin{array}{l}\text { ECB, BLS } \\
\text { question } 3\end{array}$ \\
\hline Collateral Required & $\begin{array}{l}\text { Percentage of banks reporting "collateral requirements" tightened } \\
\text { considerably for approving loans over the previous quarter }\end{array}$ & Percent & $\begin{array}{l}\text { ECB, BLS } \\
\text { question } 3\end{array}$ \\
\hline Covenants & $\begin{array}{l}\text { Percentage of banks reporting "loan covenants" tightened consider- } \\
\text { ably for approving loans over the previous quarter }\end{array}$ & Percent & $\begin{array}{l}\text { ECB, BLS } \\
\text { question } 3\end{array}$ \\
\hline Loan Demand Net Increase & $\begin{array}{l}\text { Net percentage of banks reporting an increase in long-term loan de- } \\
\text { mand over the previous quarter }\end{array}$ & Percent & $\begin{array}{l}\text { ECB, BLS } \\
\text { question } 4\end{array}$ \\
\hline
\end{tabular}




\section{Appendix B: Bank Lending Survey Questions on Loans or Credit Lines to Enterprises}

Q1: Over the past three months, how have your bank's credit standards as applied to the approval of loans or credit lines to enterprises changed?

Q2: Over the past three months, how have the following factors affected your bank's credit standards as applied to the approval of loans or credit lines to enterprises (as described in question 1)? Please rate the contribution of the following factors to the tightening or easing of credit standards using the following scale:

$--=$ contributed considerably to tightening of credit standards

$-=$ contributed somewhat to tightening of credit standards

$\bigcirc=$ contributed to basically unchanged credit standards

$+=$ contributed somewhat to easing of credit standards

$++=$ contributed considerably to easing of credit standards

A) Cost of funds and balance sheet constraints

- Costs related to your bank's capital position

- Your bank's ability to access market financing

- Your bank's liquidity position

B) Pressure from competition

- Competition from other banks

- Competition from non-banks

- Competition from market financing

C) Perception of risk

- Expectations regarding general economic activity 
- Industry or firm-specific outlook

- Risk on the collateral demanded

Q3: Over the past three months, how have your bank's conditions and terms for approving loans or credit lines to enterprises changed? Please rate each factor using the following scale:

$--=$ tightened considerably

$-=$ tightened somewhat

$\bigcirc=$ remained basically unchanged

$+=$ eased somewhat

$++=$ eased considerably

A) Price

- Your bank's margin on average loans (wider margin = tightened, narrower margin $=$ eased)

- Your bank's margin on riskier loans

B) Other conditions and terms

- Non-interest rate charges

- Size of the loan or credit line

- Collateral requirements

- Loan covenants

- Maturity

Q4: Over the past three months, how has the demand for loans or credit lines to enterprises changed at your bank, apart from normal seasonal fluctuations?

Q5: Over the past three months, how have the following factors affected the demand for loans or credit lines to enterprises (as described in question 4 in the column headed "Overall")? Please rate each possible factor using the following scale:

$--=$ contributed considerably to lower demand 
$-=$ contributed somewhat to lower demand

$=$ contributed to basically unchanged demand

$+=$ contributed somewhat to higher demand

$++=$ contributed considerably to higher demand

A) Financial needs

- Fixed investment

- Inventories and working capital

- Mergers / acquisitions and corporate restructuring

- Debt restructuring

B) Use of alternative fiannce

- Internal financing

- Loans from other banks

- Loans from non-banks

- Issuance of debt securities

- Issuance of equity

Q6: Please indicate how you expect your bank's credit standards as applied to the approval of loans or credit lines to enterprises to change over the next three months. (forward-looking version of Q1)

Q7: Please indicate how you expect demand for loans or credit lines to enterprises to change at your bank over the next three months (apart from normal seasonal fluctuations). (forward-looking version of Q4) 
Figure 1: EU NFC Financing Sources Outstanding (EUR bn)

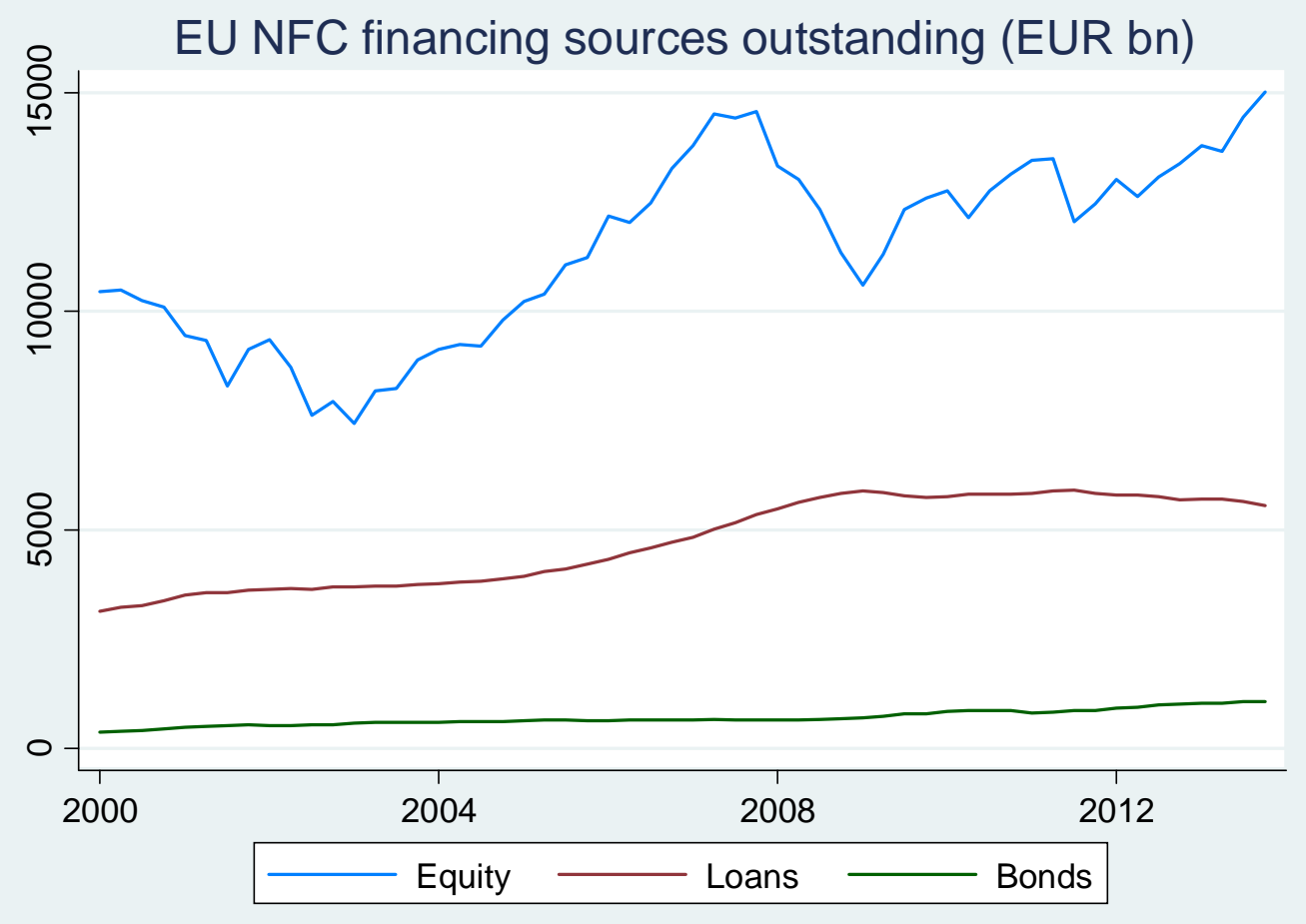

Figure 2: EU NFC Gross Bond and Bank Loan Issuance (EUR bn)

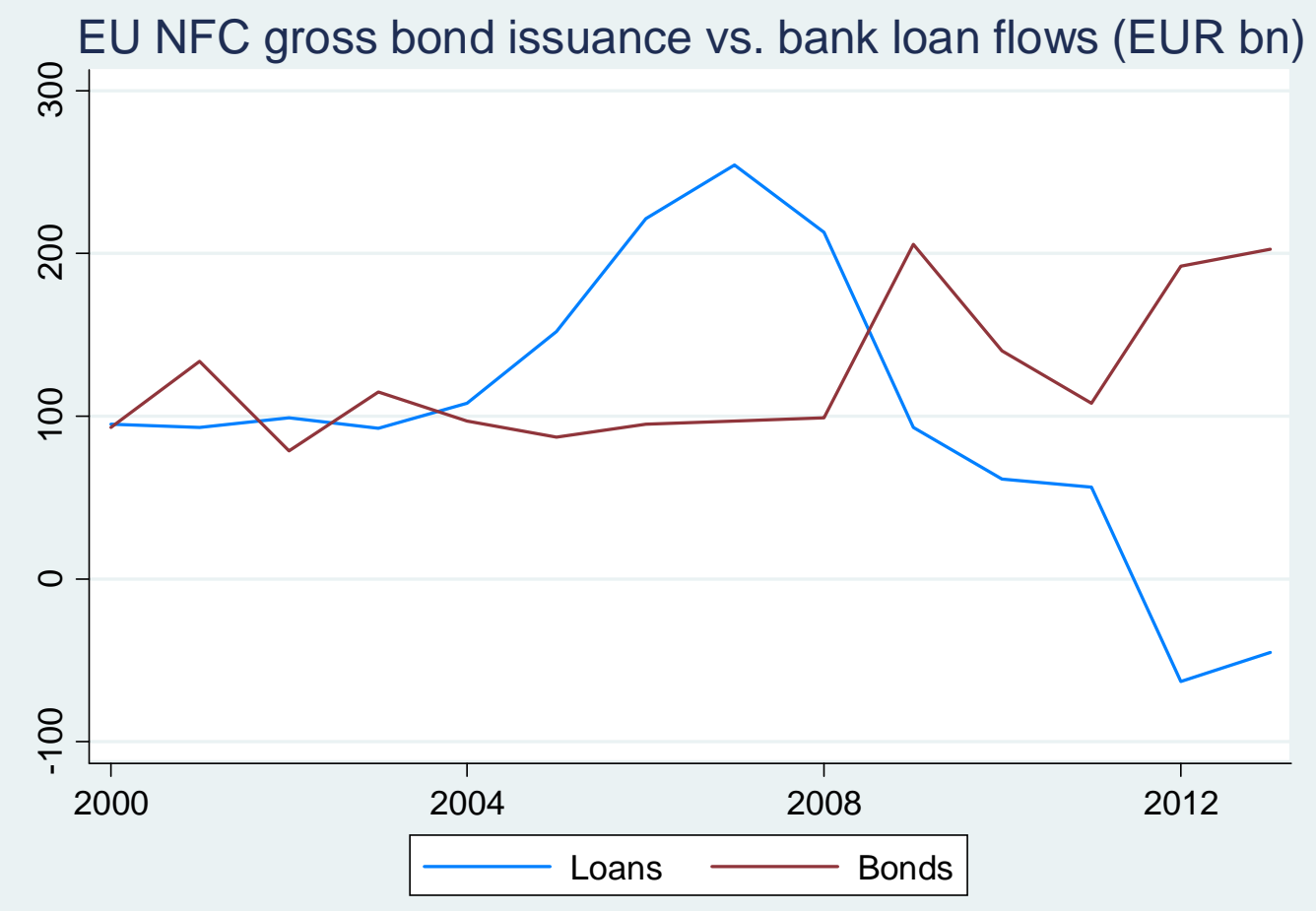


Figure 3: EU NFC Security Annual Growth Rate

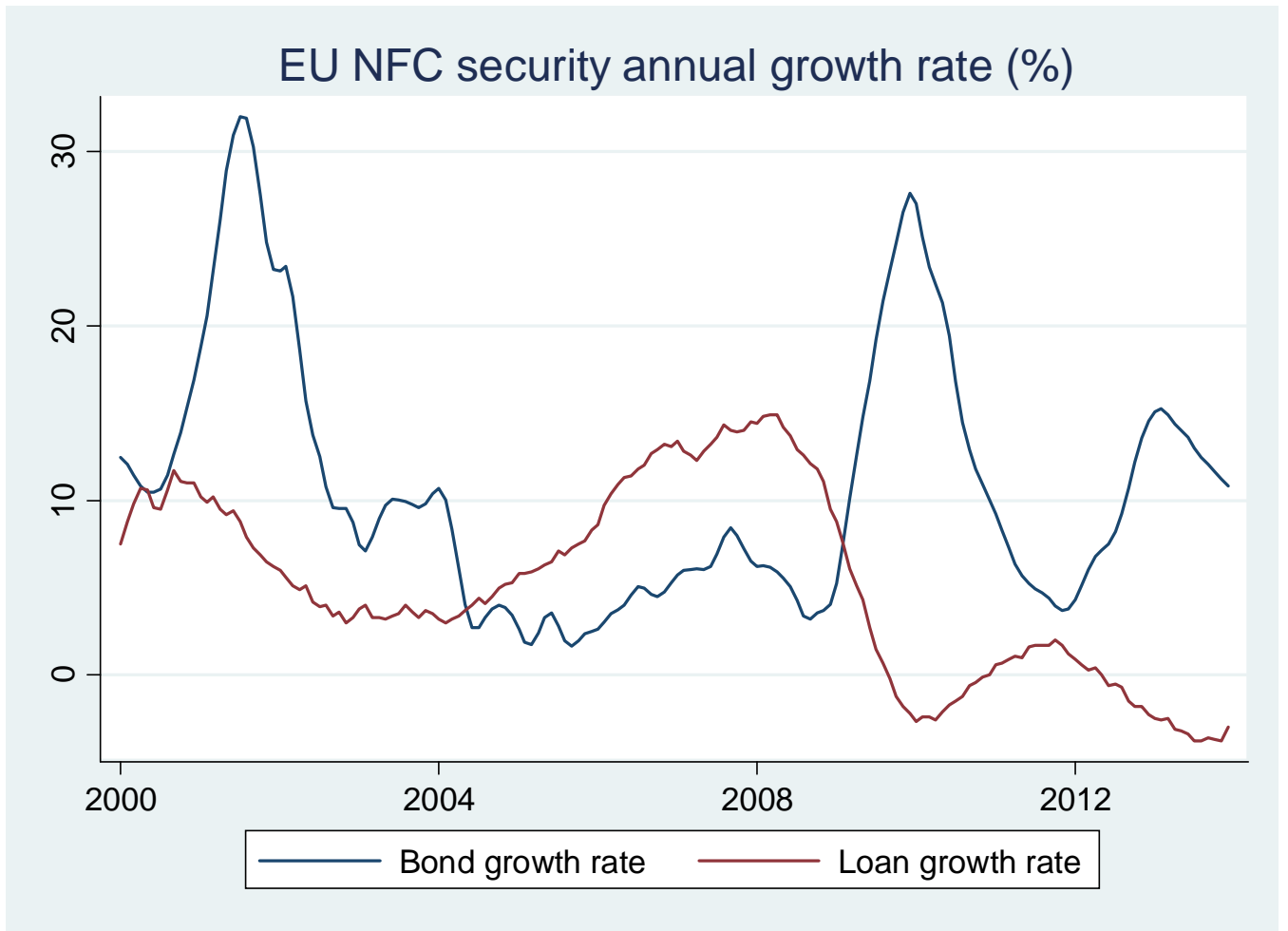

Figure 4: Euro Area BLS Q1: Bank's Credit Standards, Considerably Tightened

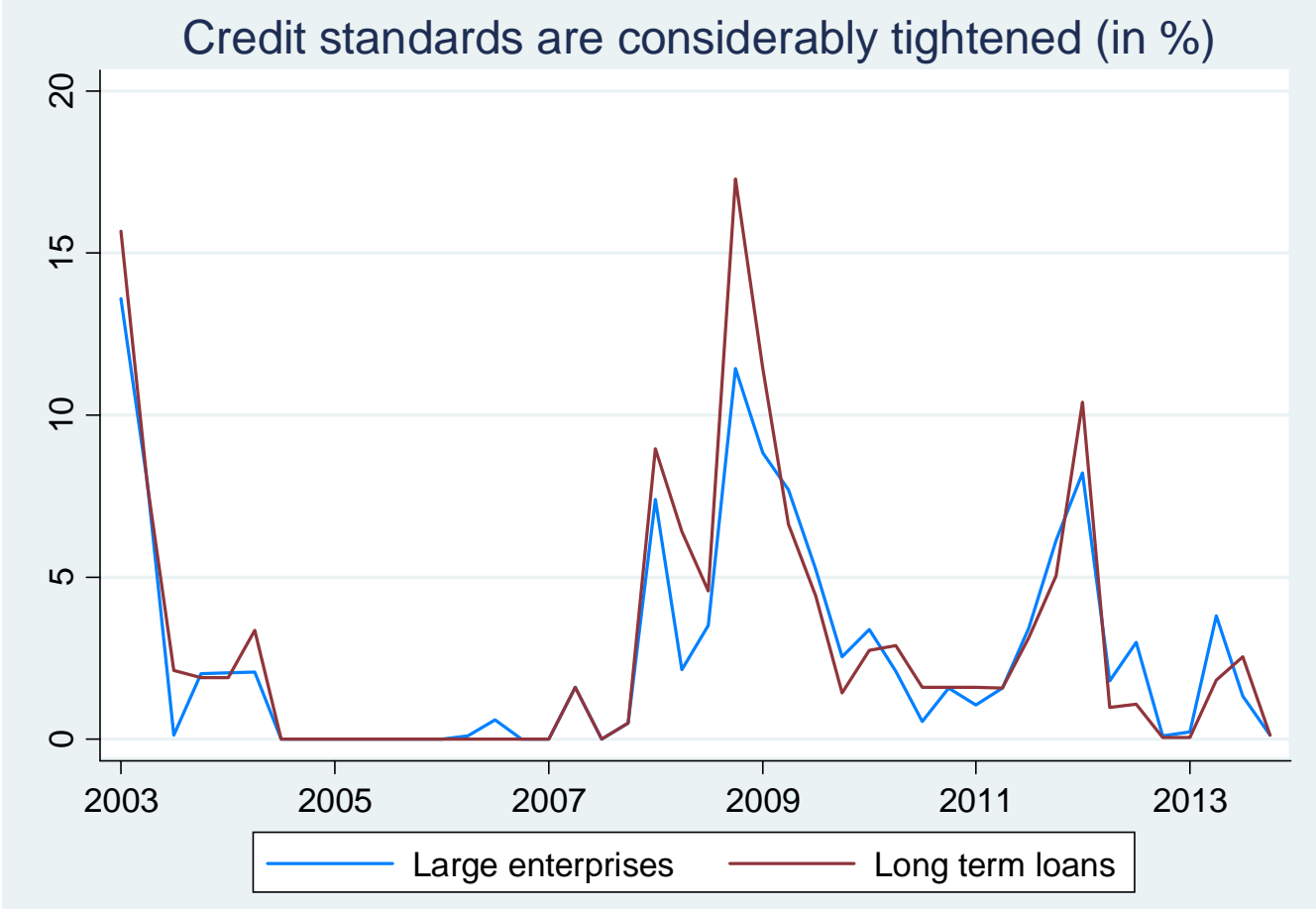


Figure 5: Euro Area BLS Q2: Factors Contributing Considerably to Tightening of Credit Standardson Overall Loans
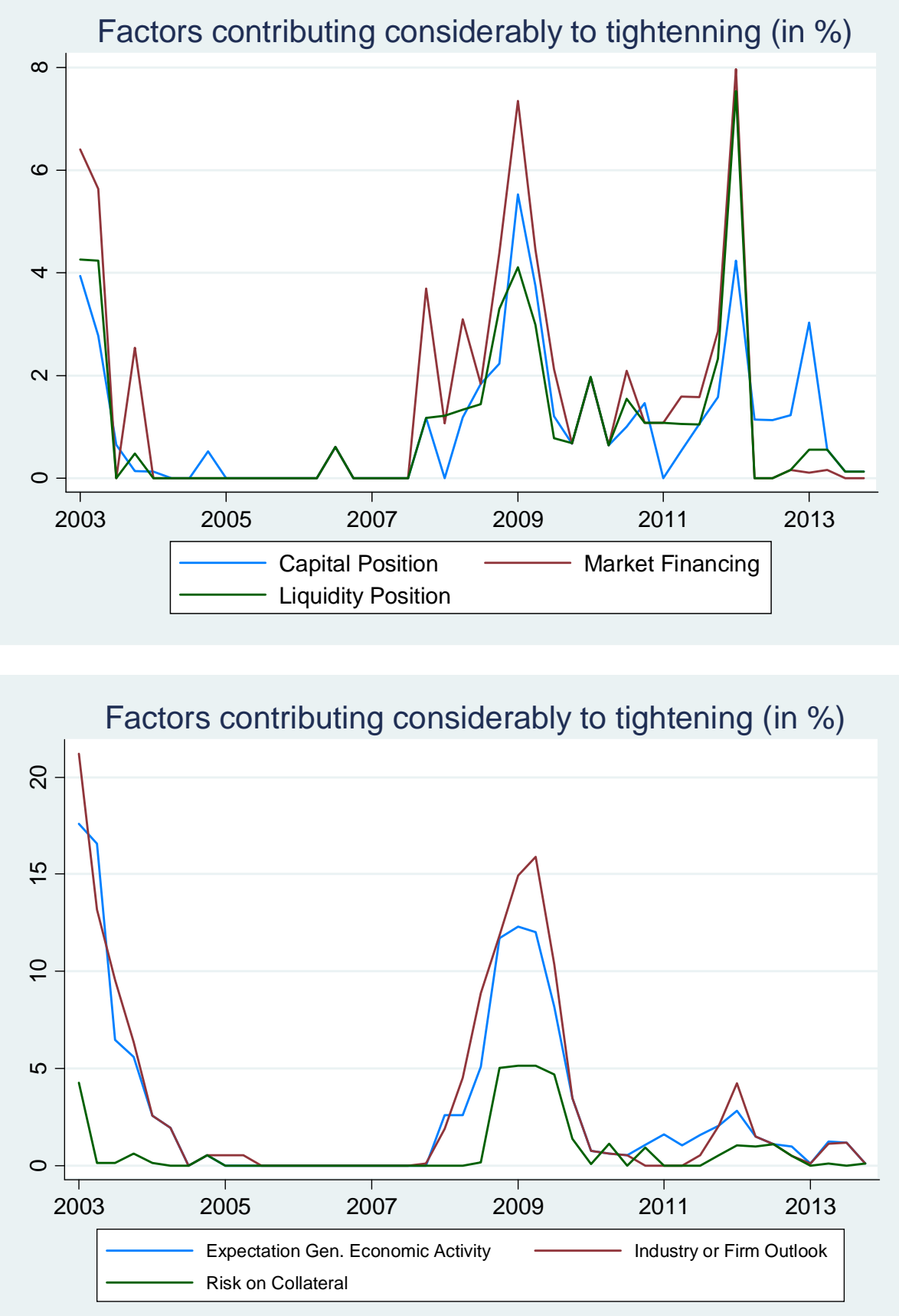
Figure 6: Euro Area BLS Q3: Change in Conditions and Terms for Approving Oveall Loans, Considerably Tightened

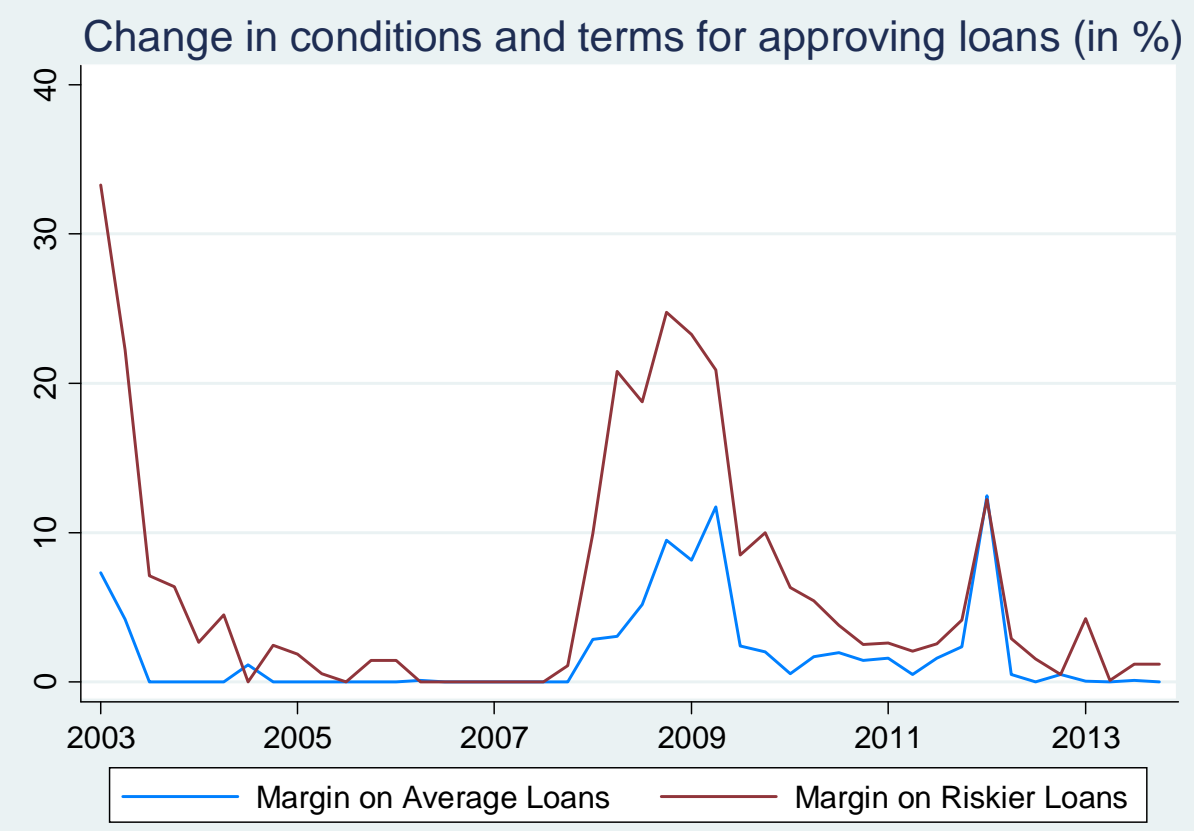

Change in conditions and terms for approving loans (in \%)

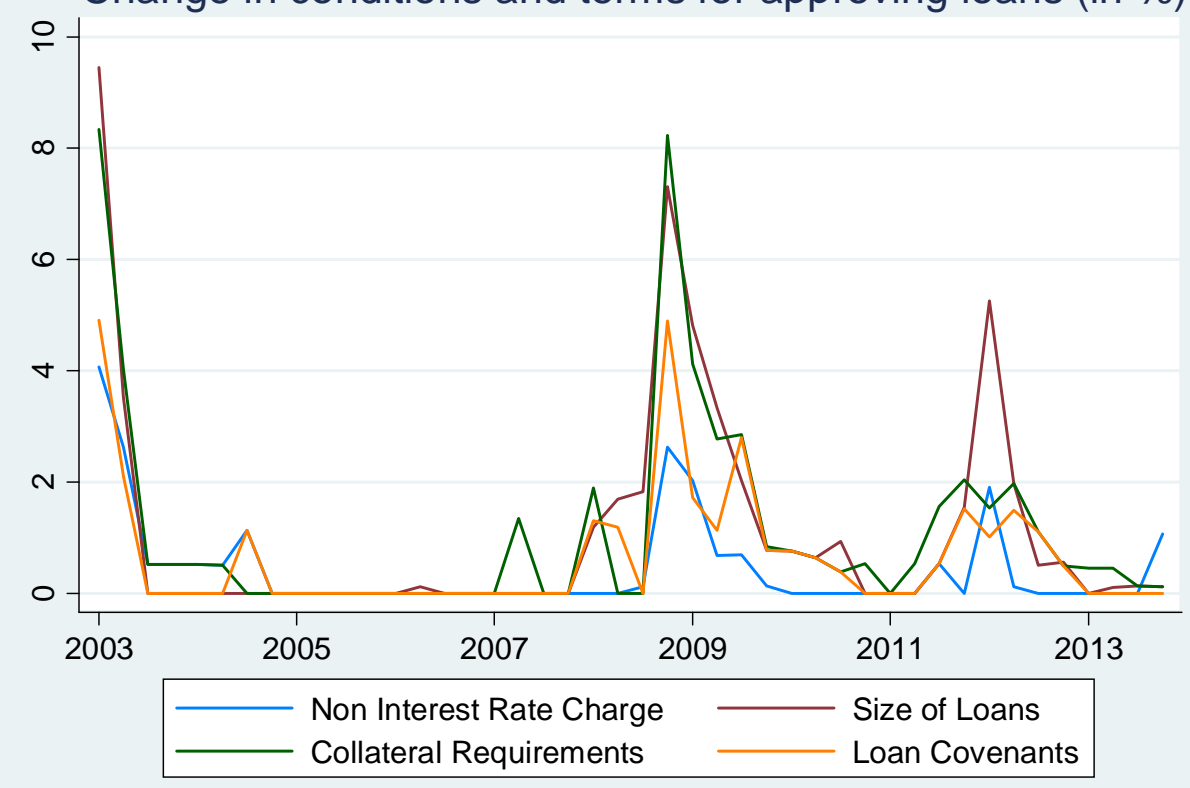


Figure 7: Percentage of Corporate Bond Issuance of Core Countries

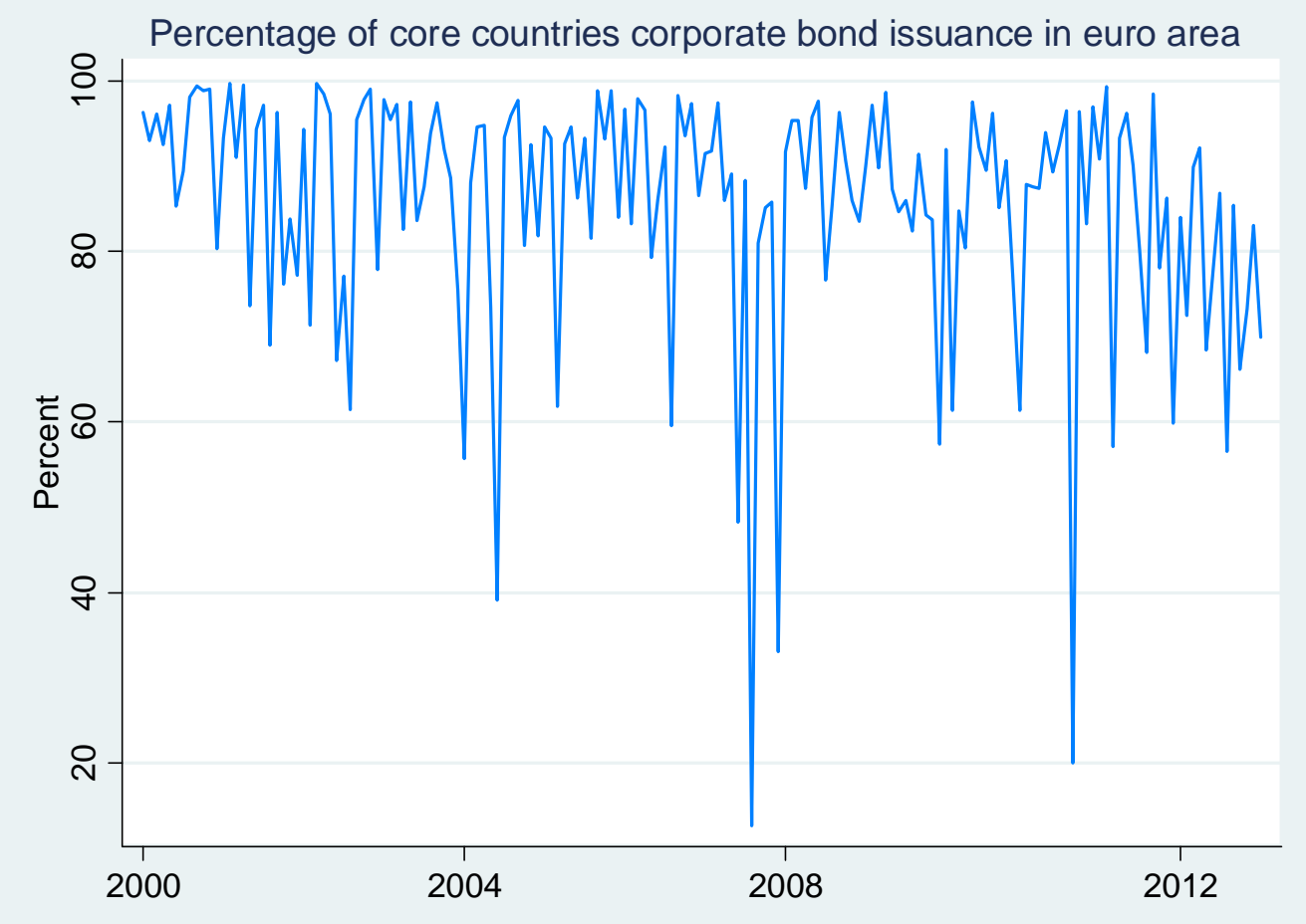




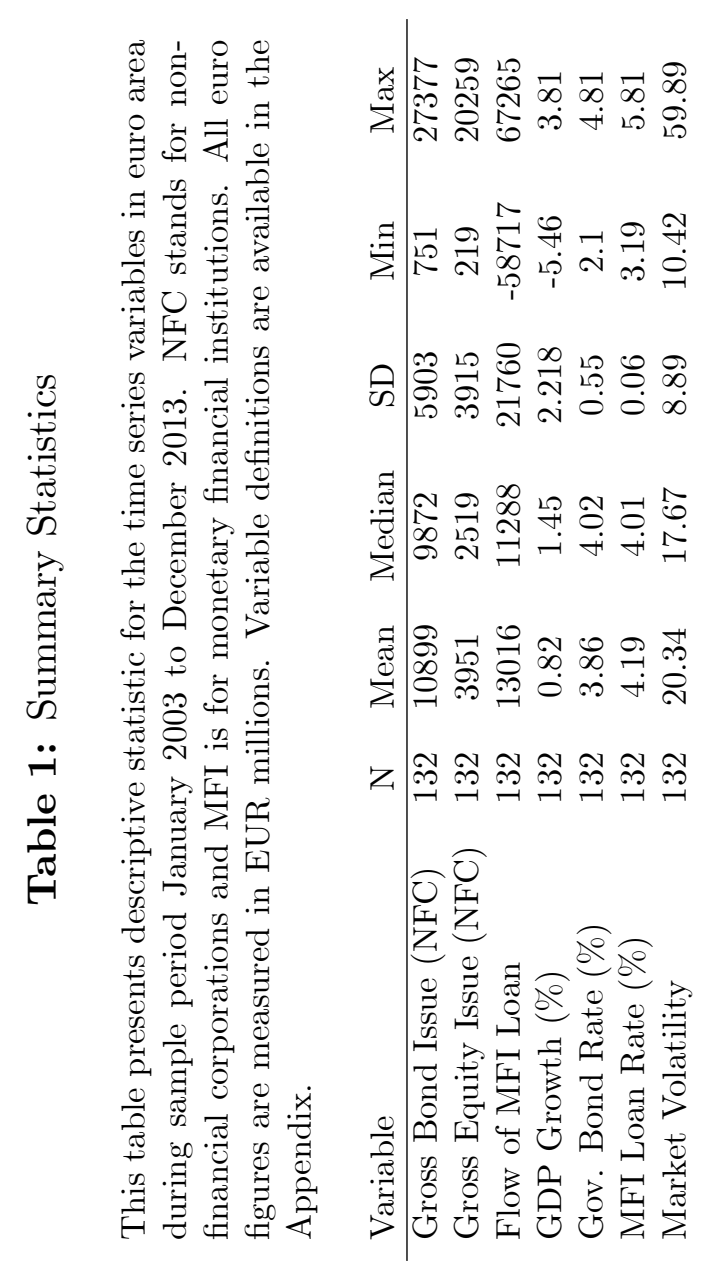


Table 2: Time Series Correlation Matrix

This table lists Pearson pairwise correlations between bond issue, equity issue and loan borrowing of non financial corporations in euro area and in core countries during sample period January 2003 to December 2013. * presents significance at $1 \%$. Variable definitions are available in the Appendix.

Panel A: EU, Gross Debt and Equity

\begin{tabular}{|c|c|c|c|}
\hline & $(1)$ & $(2)$ & $(3)$ \\
\hline (1) Gross NFC Bond Issue & 1 & & \\
\hline (2) Gross NFC Equity Issue & 0.14 & 1 & \\
\hline (3) Loan Flow to NFC & $-0.26^{*}$ & 0.09 & 1 \\
\hline \multicolumn{4}{|c|}{ Panel B: Core Economies, Gross Debt and Equity } \\
\hline & $(1)$ & $(2)$ & $(3)$ \\
\hline (1) Gross NFC Bond Issue & 1 & & \\
\hline (2) Gross NFC Equity Issue & 0.03 & 1 & \\
\hline (3) Loan Flow to NFC & $-0.29 *$ & 0.09 & 1 \\
\hline
\end{tabular}




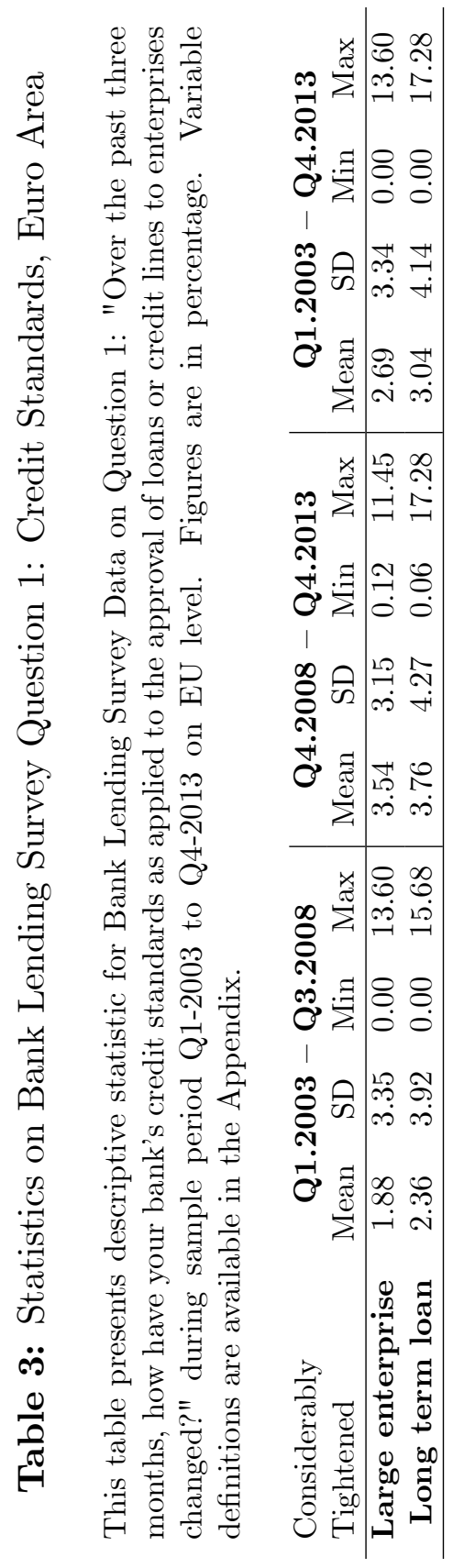




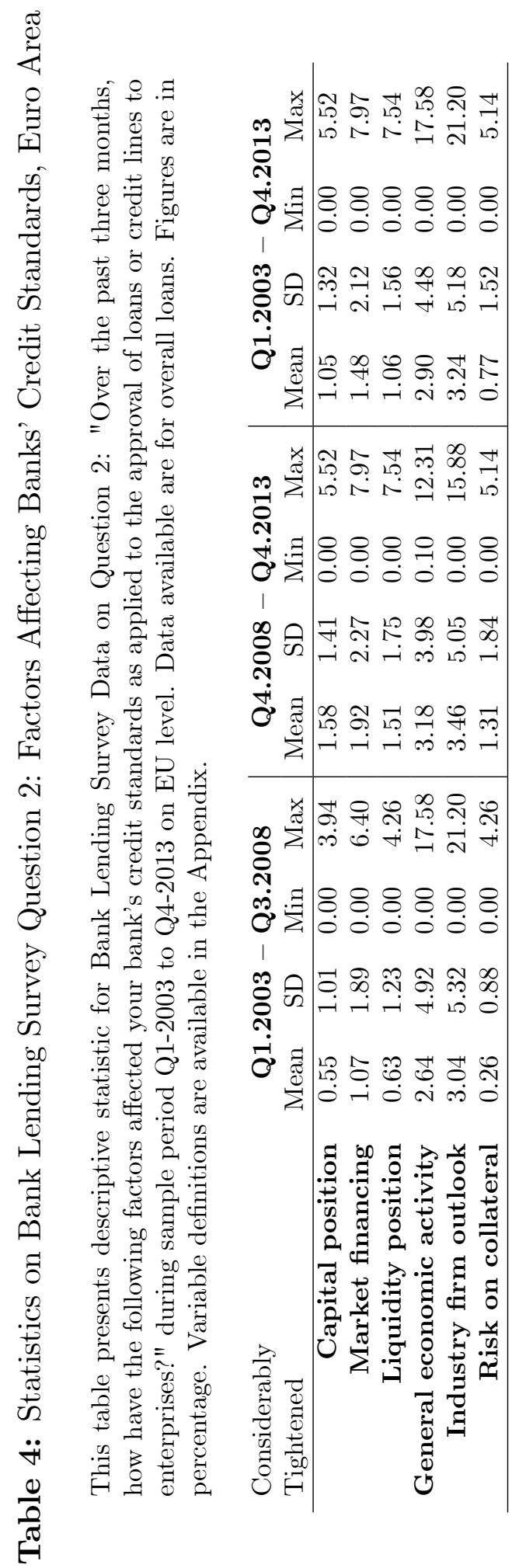




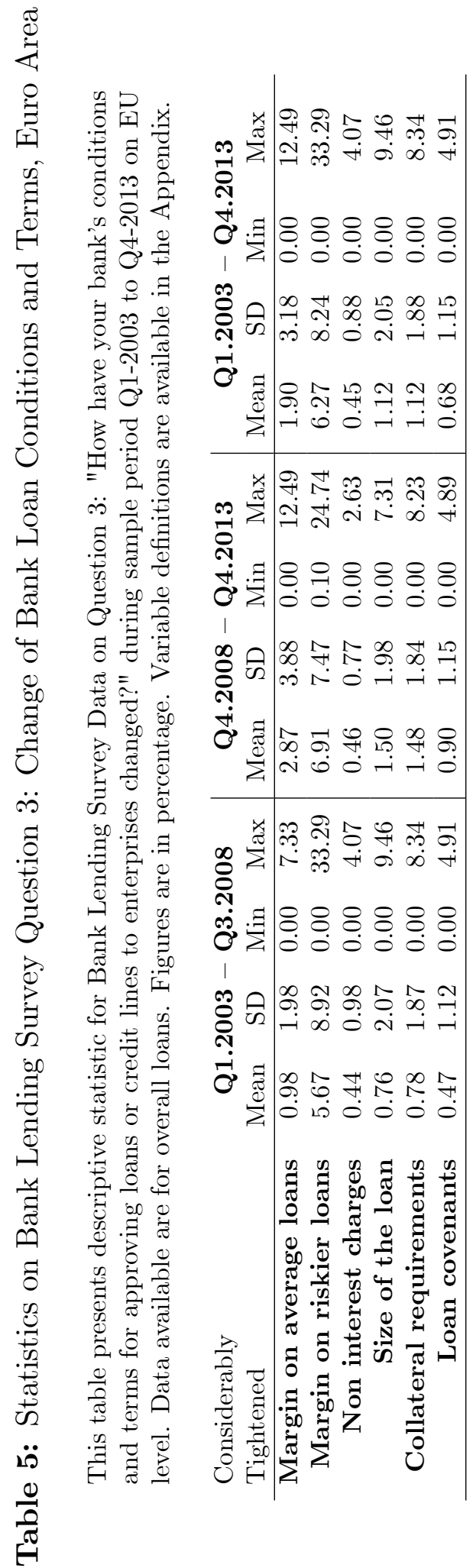


Table 6: Pairwise Granger Causality Tests

This table presents the pairwise Granger Causality Tests (Chisquared statistics) results for major time series in euro area during our sample period January 2003 to December 2013. Bond and Equity are in gross terms.

\begin{tabular}{lccc}
\hline & Lag 1 & Lag 2 & Lag 3 \\
Equity Granger-cause Bond & 0.6903 & 3.3208 & $8.1004^{* *}$ \\
Bond Granger-cause Equity & 0.0051 & 0.8225 & 2.0392 \\
& & & \\
& Lag 1 & Lag 2 & Lag 3 \\
Loan Flow Granger-cause Bond & $8.6429^{* * *}$ & $7.7859^{* *}$ & $8.1962^{* *}$ \\
Bond Granger-cause Loan Flow & $10.254^{* * *}$ & 3.137 & 5.6455 \\
\hline **, *** Statistically distinct from zero at the $5 \%$ and 1\% level, \\
respectively.
\end{tabular}


Table 7: Regression of Corporate Bond Issuance on BLS Q1 in Euro Area

For Euro area, this table presents estimations of gross corporate bond issuance regressing on BLS Question 1 of overall credit standards considerable tightening, Question 4 of net loan demand increase, actual loan flow, macro controls, and year dummies, during sample period January 2003 to December 2013. Year dummies are not shown to save space. Standard errors robust to heteroskedasticity are reported in parentheses. Variable definitions are dedicated to the Appendix.

\begin{tabular}{|c|c|c|c|c|}
\hline & \multicolumn{2}{|c|}{$\begin{array}{l}\text { Long Term Loan } \\
\text { (1) }\end{array}$} & \multicolumn{2}{|c|}{ Large Enterprise } \\
\hline Loan Flow & $\begin{array}{c}-0.00^{* *} \\
(0.00)\end{array}$ & $\begin{array}{c}-0.00^{* *} \\
(0.00)\end{array}$ & $\begin{array}{c}-0.01^{* *} \\
(0.00)\end{array}$ & $\begin{array}{c}-0.01^{* *} \\
(0.00)\end{array}$ \\
\hline GDP Growth & $\begin{array}{l}-0.06 \\
(0.05)\end{array}$ & $\begin{array}{c}0.01 \\
(0.06)\end{array}$ & $\begin{array}{l}-0.07 \\
(0.06)\end{array}$ & $\begin{array}{l}-0.05 \\
(0.07)\end{array}$ \\
\hline EU Gov. Bond Rate & $\begin{array}{l}-0.00 \\
(0.14)\end{array}$ & $\begin{array}{l}-0.00 \\
(0.14)\end{array}$ & $\begin{array}{c}0.04 \\
(0.14)\end{array}$ & $\begin{array}{c}0.05 \\
(0.14)\end{array}$ \\
\hline Market Volatility & $\begin{array}{c}-0.02^{* *} \\
(0.01)\end{array}$ & $\begin{array}{c}-0.03^{* *} \\
(0.01)\end{array}$ & $\begin{array}{l}-0.02^{*} \\
(0.01)\end{array}$ & $\begin{array}{c}-0.02^{* *} \\
(0.01)\end{array}$ \\
\hline Considerably Tightened & $\begin{array}{c}0.07^{* * *} \\
(0.02)\end{array}$ & $\begin{array}{c}0.08^{* * *} \\
(0.02)\end{array}$ & & \\
\hline Loan Demand & & $\begin{array}{l}-0.01^{*} \\
(0.01)\end{array}$ & & \\
\hline Considerably Tightened & & & $\begin{array}{c}0.06^{* * * *} \\
(0.02)\end{array}$ & $\begin{array}{c}0.06^{* * * *} \\
(0.02)\end{array}$ \\
\hline Loan Demand & & & & $\begin{array}{l}-0.01 \\
(0.01)\end{array}$ \\
\hline Constant & $\begin{array}{c}9.52^{* * *} \\
(0.64)\end{array}$ & $\begin{array}{c}9.29^{* * *} \\
(0.65)\end{array}$ & $\begin{array}{c}9.31^{* * *} \\
(0.63)\end{array}$ & $\begin{array}{c}9.13^{* * *} \\
(0.71)\end{array}$ \\
\hline Year Fixed Effects & YES & YES & YES & YES \\
\hline $\mathrm{R} 2$ & $36 \%$ & $38 \%$ & $34 \%$ & $34 \%$ \\
\hline $\mathrm{N}$ & 132 & 132 & 132 & 132 \\
\hline F-Value & 5.81 & 5.99 & 5.82 & 5.49 \\
\hline F-statistic 2009-2012 & 1.40 & 2.23 & 1.44 & 1.63 \\
\hline Durbin-Watson Test & 2.04 & 2.09 & 1.99 & 1.98 \\
\hline
\end{tabular}


Table 8a: Regression of Corporate Bond Issuance on BLS Q2 in Euro Area

For Euro area, this table presents estimations of gross corporate bond issuance regressing on BLS Question 2 of factors contributing considerably to tightening of banks' credit standards, Question 4 of net loan demand increase, actual loan flow, macro controls, and year dummies, during sample period January 2003 to December 2013. Panel A contains results on "cost of funds and balance sheet constraints" relevance. Panel B includes "perception of risk" factors. Year dummies are not shown to save space. Standard errors robust to heteroskedasticity are reported in parentheses. Variable definitions are dedicated to the Appendix.

Panel A: Cost of Funds and Balance Sheet Constraints

\begin{tabular}{lcc|cc|cc} 
& \multicolumn{2}{c|}{ Capital Position } & \multicolumn{2}{c|}{ Market } & Financing & \multicolumn{2}{c}{$\begin{array}{c}\text { Liquidity } \\
\text { Position }\end{array}$} \\
& $(1)$ & $(2)$ & $(3)$ & $(4)$ & $(5)$ & $(6)$ \\
\hline Loan Flow & $-0.01^{* *}$ & $-0.01^{* *}$ & $-0.01^{* *}$ & $-0.01^{* *}$ & $-0.01^{* *}$ & $-0.01^{* *}$ \\
& 0 & 0 & 0 & 0 & 0 & 0 \\
GDP Growth & -0.05 & -0.03 & -0.05 & -0.03 & -0.07 & -0.04 \\
& -0.07 & -0.09 & -0.06 & -0.07 & -0.06 & -0.08 \\
EU Gov. Bond Rate & 0.06 & 0.07 & -0.02 & 0 & 0.02 & 0.03 \\
& -0.14 & -0.14 & -0.15 & -0.15 & -0.15 & -0.15 \\
Market Volatility & -0.01 & -0.01 & -0.01 & -0.01 & -0.01 & -0.01 \\
& -0.01 & -0.01 & -0.01 & -0.01 & -0.01 & -0.01 \\
Loan Demand & & 0 & & 0 & & -0.01 \\
& & -0.01 & & -0.01 & & -0.01 \\
Capital Position & 0.07 & 0.08 & & & & \\
& -0.06 & -0.06 & & & & \\
Market Financing & & & $0.07^{* *}$ & $0.07^{* * *}$ & & \\
Liquidity Position & & & -0.03 & -0.03 & & \\
& & & & & $0.07^{* *}$ & $0.07^{* *}$ \\
Constant & & & & -0.03 & -0.03 \\
& $9.07^{* * *}$ & $8.94^{* * *}$ & $9.29^{* * *}$ & $9.15^{* * *}$ & $9.27^{* * *}$ & $9.08^{* * *}$ \\
Year Fixed Effects & -0.62 & -0.73 & -0.65 & -0.73 & -0.64 & -0.73 \\
R2 & YES & YES & YES & YES & YES & YES \\
N & $32 \%$ & $32 \%$ & $34 \%$ & $34 \%$ & $32 \%$ & $33 \%$ \\
F-Value & 132 & 132 & 132 & 132 & 132 & 132 \\
F-statistic 2009-2012 & 6.39 & 6.07 & 6.28 & 5.99 & 5.98 & 5.72 \\
Durbin-Watson Test & 0.77 & 0.81 & 0.98 & 1.09 & 0.74 & 0.85 \\
\hline , & 1.94 & 1.94 & 1.99 & 1.98 & 1.95 & 1.95 \\
\hline
\end{tabular}

$*, * *, * * *$ Statistically distinct from zero at the $10 \%, 5 \%$ and $1 \%$ level, respectively. 


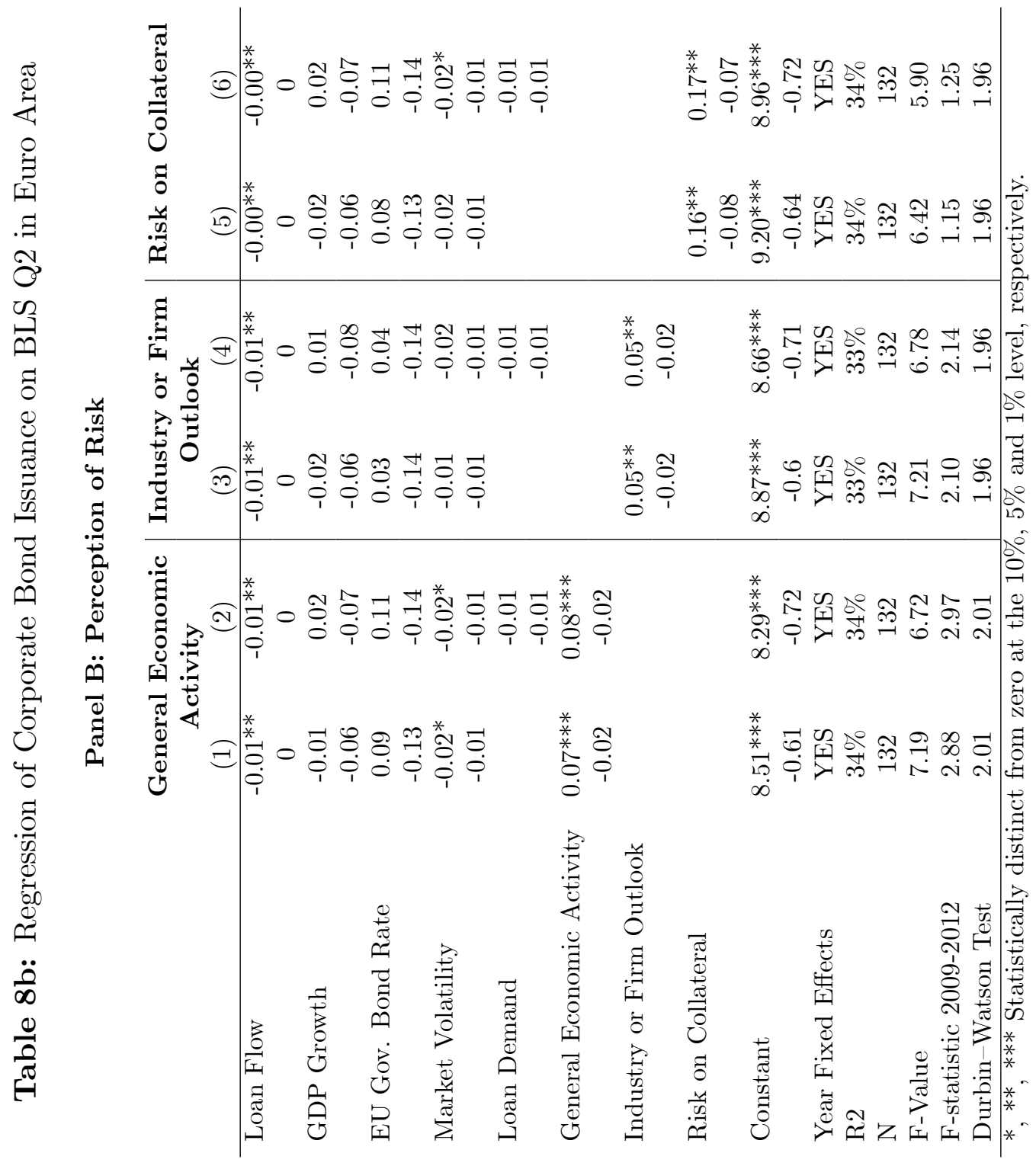


Table 9a: Regression of Corporate Bond Issuance on BLS Q3 in Euro Area

For Euro area, this table presents estimations of gross corporate bond issuance regressing on BLS Question 3 of banks' considerably tightened conditions and terms for approving loans, Question 4 of net loan demand increase, actual loan flow, macro controls, and year dummies, during sample period January 2003 to December 2013. Panel A contains results on price-related terms. Panel B includes non-price terms. Year dummies are not shown to save space. Standard errors robust to heteroskedasticity are reported in parentheses. Variable definitions are dedicated to the Appendix.

Panel A: Price Terms

\begin{tabular}{lcc|cc} 
& \multicolumn{2}{c}{ Margin Average } & \multicolumn{2}{c}{ Margin Riskier } \\
& \multicolumn{2}{c}{ Loan } & \multicolumn{2}{c}{ Loan } \\
& $-0.01^{* *}$ & $-0.01^{* *}$ & $-0.01^{* *}$ & $-0.01^{* *}$ \\
\hline Loan Flow & $(0.00)$ & $(0.00)$ & $(0.00)$ & $(0.00)$ \\
GDP Growth & -0.06 & -0.01 & -0.05 & -0.04 \\
& $(0.06)$ & $(0.08)$ & $(0.06)$ & $(0.07)$ \\
EU Gov. Bond Rate & 0.00 & 0.01 & 0.00 & 0.00 \\
& $(0.15)$ & $(0.15)$ & $(0.14)$ & $(0.14)$ \\
Market Volatility & -0.01 & -0.01 & $-0.02^{*}$ & $-0.02^{*}$ \\
& $(0.01)$ & $(0.01)$ & $(0.01)$ & $(0.01)$ \\
Loan Demand & & -0.01 & & 0.00 \\
& & $(0.01)$ & & $(0.01)$ \\
Margin Average Loan & $0.04^{* *}$ & $0.05^{* *}$ & & \\
& $(0.02)$ & $(0.02)$ & & \\
Margin Riskier Loan & & & $0.03^{* * *}$ & $0.03^{* * *}$ \\
& & & $(0.01)$ & $(0.01)$ \\
Constant & $9.43^{* * *}$ & $9.18^{* * *}$ & $9.10^{* * *}$ & $9.06^{* * *}$ \\
& $(0.64)$ & $(0.71)$ & $(0.61)$ & $(0.70)$ \\
Year Fixed Effects & YES & YES & YES & YES \\
& & & & \\
R2 & $33 \%$ & $33 \%$ & $35 \%$ & $35 \%$ \\
N & 132 & 132 & 132 & 132 \\
F-Value & 6.98 & 7.03 & 8.30 & 7.95 \\
F-statistic 2009-2012 & 0.61 & 0.75 & 2.07 & 1.97 \\
Durbin-Watson Test & 1.96 & 1.96 & 2.01 & 2.01 \\
\hline
\end{tabular}

$*, * *, * * *$ Statistically distinct from zero at the $10 \%, 5 \%$

and $1 \%$ level, respectively. 


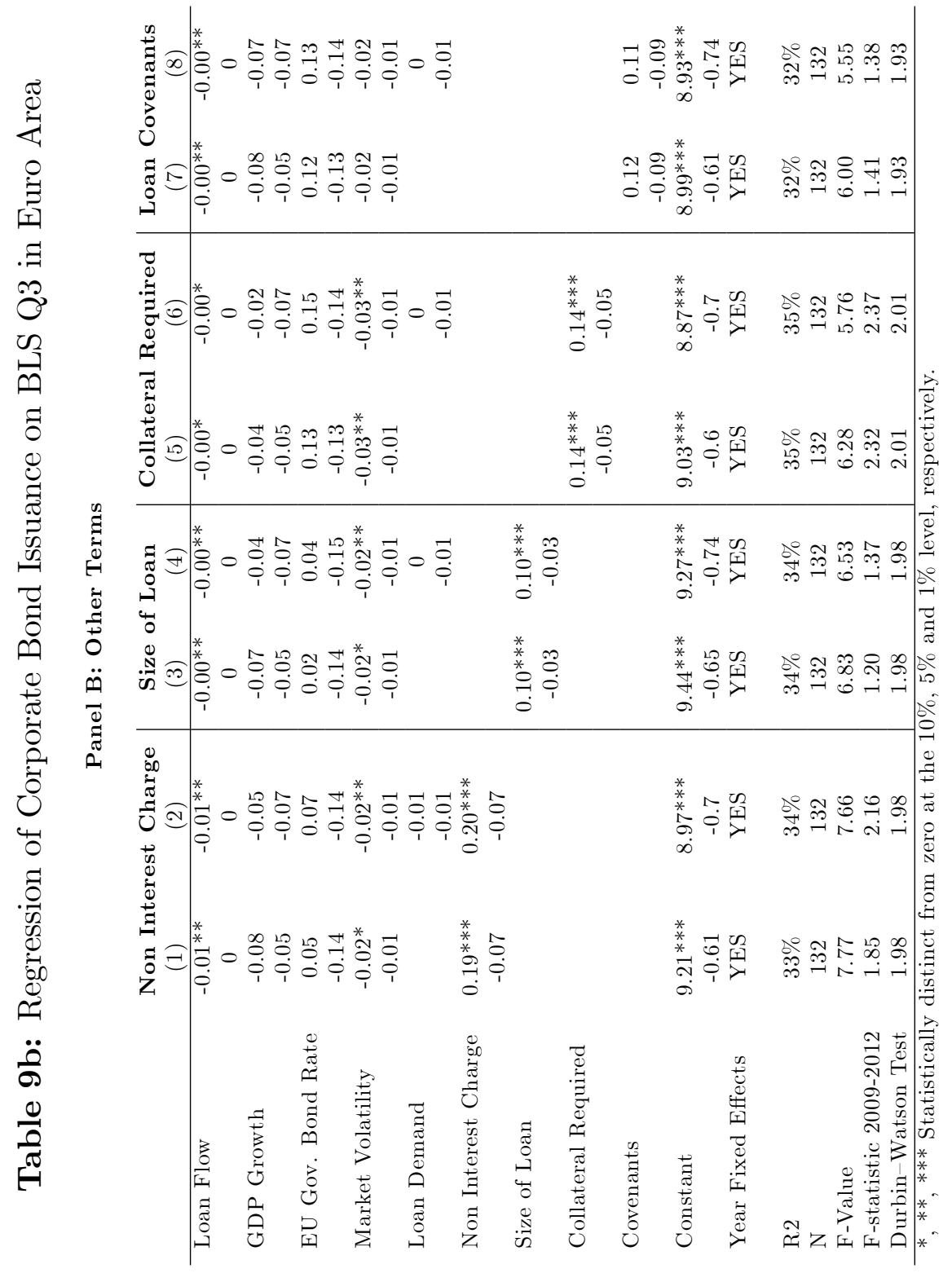


Table 10a: Regression of Corporate Bond Issuance on BLS Q1 in Core and Periphery Countries

This table presents estimations of gross corporate bond issuance regressing on BLS Question 1 of overall credit standards considerable tightening, Question 4 of net loan demand increase, actual loan flow, macro controls, and year dummies, during sample period January 2003 to December 2013. Panel A gives the results for core economies and Panel B shows the results for periphery countries. Year dummies are not shown to save space. Standard errors robust to heteroskedasticity are reported in parentheses. Variable definitions are dedicated to the Appendix.

Panel A: Core Countries

\begin{tabular}{lcc|cc} 
& \multicolumn{2}{c}{ Long Term Loan } & \multicolumn{2}{c}{ Large Enterprise } \\
& $(\mathbf{1})$ & $\mathbf{( 2 )}$ & $\mathbf{( 3 )}$ & $\mathbf{( 4 )}$ \\
\hline Loan Flow - Core & 0.02 & 0.02 & 0.02 & 0.02 \\
& $(0.01)$ & $(0.01)$ & $(0.02)$ & $(0.02)$ \\
GDP Growth - Core & $-0.13^{*}$ & -0.07 & $-0.13^{*}$ & -0.12 \\
& $(0.07)$ & $(0.07)$ & $(0.07)$ & $(0.08)$ \\
Gov. Bond Rate - Gore & -0.04 & -0.03 & 0.04 & 0.05 \\
& $(0.25)$ & $(0.25)$ & $(0.24)$ & $(0.23)$ \\
Market Volatility & $-0.03^{*}$ & $-0.04^{*}$ & -0.03 & -0.03 \\
& $(0.02)$ & $(0.02)$ & $(0.02)$ & $(0.02)$ \\
Considerably Tightened & $0.07^{* * *}$ & $0.09^{* * *}$ & & \\
& $(0.03)$ & $(0.03)$ & & \\
Loan Demand Net Increase & & $-0.01^{*}$ & & \\
& & $(0.01)$ & & \\
Considerably Tightened & & & $0.07^{* *}$ & $0.07^{* *}$ \\
& & & $(0.03)$ & $(0.03)$ \\
Loan Demand Net Increase & & & & -0.00 \\
& & & & $(0.01)$ \\
Constant & $9.70^{* * *}$ & $9.45^{* * *}$ & $9.27^{* * *}$ & $9.21^{* * *}$ \\
& $(1.23)$ & $(1.21)$ & $(1.16)$ & $(1.15)$ \\
Year Fixed Effects & YES & YES & YES & YES \\
& & & & \\
R2 & $30 \%$ & $31 \%$ & $29 \%$ & $29 \%$ \\
N & 132 & 132 & 132 & 132 \\
F-Value & 5.59 & 5.59 & 5.45 & 5.14 \\
F-statistic 2009-2012 & 0.68 & 1.30 & 0.70 & 0.74 \\
Durbin-Watson Test & 2.23 & 2.27 & 2.18 & 2.18 \\
\hline & & &
\end{tabular}

$*, * *, * * *$ Statistically distinct from zero at the $10 \%, 5 \%$ and $1 \%$ level, respectively. 
Table 10b: Regression of Corporate Bond Issuance on BLS Q1 in Core and Periphery Countries

\section{Panel B: Periphery Countries}

\begin{tabular}{|c|c|c|c|c|}
\hline & $\begin{array}{l}\text { Long } \mathrm{Te} \\
\text { (1) }\end{array}$ & $\begin{array}{l}\text { m Loan } \\
(2)\end{array}$ & $\begin{array}{c}\text { Large } E \\
(3)\end{array}$ & $\begin{array}{l}\text { (4) } \\
\text { (4) }\end{array}$ \\
\hline Loan Flow - Periphery & $\begin{array}{c}0.02^{* *} \\
(0.01)\end{array}$ & $\begin{array}{c}0.02^{* *} \\
(0.01)\end{array}$ & $\begin{array}{c}0.02^{* *} \\
(0.01)\end{array}$ & $\begin{array}{c}0.02^{* *} \\
(0.01)\end{array}$ \\
\hline GDP Growth - Periphery & $\begin{array}{c}-0.37^{* *} \\
(0.15)\end{array}$ & $\begin{array}{c}-0.30^{*} \\
(0.17)\end{array}$ & $\begin{array}{c}-0.36^{* *} \\
(0.15)\end{array}$ & $\begin{array}{c}-0.33^{*} \\
(0.18)\end{array}$ \\
\hline Gov. Bond Rate - Periphery & $\begin{array}{l}-0.26 \\
(0.23)\end{array}$ & $\begin{array}{l}-0.27 \\
(0.23)\end{array}$ & $\begin{array}{l}-0.27 \\
(0.23)\end{array}$ & $\begin{array}{l}-0.26 \\
(0.22)\end{array}$ \\
\hline Market Volatility & $\begin{array}{c}-0.06^{* * *} \\
(0.02)\end{array}$ & $\begin{array}{c}-0.06^{* * *} \\
(0.02)\end{array}$ & $\begin{array}{c}-0.05 * * * \\
(0.02)\end{array}$ & $\begin{array}{c}-0.05^{* * *} \\
(0.02)\end{array}$ \\
\hline Considerably Tightened & $\begin{array}{c}0.06 \\
(0.05)\end{array}$ & $\begin{array}{c}0.07 \\
(0.05)\end{array}$ & & \\
\hline Loan Demand Net Increase & & $\begin{array}{l}-0.01 \\
(0.02)\end{array}$ & & \\
\hline Considerably Tightened & & & $\begin{array}{c}0.06 \\
(0.05)\end{array}$ & $\begin{array}{c}0.06 \\
(0.05)\end{array}$ \\
\hline Loan Demand Net Increase & & & & $\begin{array}{l}-0.00 \\
(0.02)\end{array}$ \\
\hline Constant & $\begin{array}{c}8.86^{* * *} \\
(1.00)\end{array}$ & $\begin{array}{c}8.68^{* * *} \\
(0.99)\end{array}$ & $\begin{array}{c}8.82^{* * *} \\
(1.01)\end{array}$ & $\begin{array}{c}8.67^{* * *} \\
(1.05)\end{array}$ \\
\hline Year Fixed Effects & YES & YES & YES & YES \\
\hline R2 & $31 \%$ & $32 \%$ & $31 \%$ & $31 \%$ \\
\hline $\mathrm{N}$ & 132 & 132 & 132 & 132 \\
\hline F-Value & 5.26 & 4.97 & 5.03 & 4.72 \\
\hline F-statistic 2009-2012 & 2.20 & 2.23 & 2.23 & 2.21 \\
\hline Durbin-Watson Test & 2.17 & 2.17 & 2.18 & 2.18 \\
\hline
\end{tabular}


No. Author(s)

455

Sebastien Betermier Laurent E. Calvet

Paolo Sodini

454

453

452

451

450

449

448

447

446
Andrea Zaghini

Elias Aptus

Volker Britz

Hans Gersbach

John Y. Campbell

João F. Cocco

Laura Moretti

Nikolaus Hautsch

Ostap Okhrin

Alexander Ristig

Engelbert J. Dockner

Manuel Mayer

Josef Zechner

Johann Reindl

Neal Stoughton

Josef Zechner

Jaewon Choi

Dirk Hackbarth

Josef Zechner

Giuseppe Bertola

Winfried Koeniger
Title

Who are the Value and Growth Investors?

Bank Bonds: Size, Systemic Relevance and the Sovereign

On the Economics of Crisis Contracts

A Model of Mortgage Default

The determinants of inflation differentials in the euro area

Efficient Iterative Maximum Likelihood

Estimation of High-Parameterized Time

Series Models

Sovereign Bond Risk Premiums

Market Implied Costs of Bankruptcy

Granularity of Corporate Debt

Hidden Insurance in a Moral Hazard Economy 